\title{
Field and laboratory evaluation of a high time resolution x-ray fluorescence instrument for determining the elemental composition of ambient aerosols
}

\author{
Anja H. Tremper ${ }^{1}$, Anna Font ${ }^{1}$, Max Priestman ${ }^{1}$, Samera H. Hamad ${ }^{2}$, Tsai-Chia Chung ${ }^{3}$, Ari Pribadi ${ }^{1}$, \\ Richard J. C. Brown ${ }^{4}$, Sharon L. Goddard ${ }^{4}$, Nathalie Grassineau ${ }^{3}$, Krag Petterson ${ }^{5}$, Frank J. Kelly ${ }^{1}$, and \\ David C. Green ${ }^{1}$ \\ ${ }^{1}$ MRC-PHE Centre for Environment and Health, King's College London, London, SE1 9NH, UK \\ ${ }^{2}$ Department of Behavioural and Community Health, School of Public Health, the University of Maryland, \\ College Park, MD 20742, USA \\ ${ }^{3}$ Earth Sciences Department, Royal Holloway University of London, Egham TW20 0EX, UK \\ ${ }^{4}$ Chemical, Medical and Environmental Science Department, National Physical Laboratory, Teddington, TW11 0LW, UK \\ ${ }^{5}$ Cooper Environmental Services, LLC, 9403 SW Nimbus Ave. Beaverton, OR 97062, USA
}

Correspondence: Anja H. Tremper (anja.tremper@kcl.ac.uk)

Received: 4 October 2017 - Discussion started: 14 December 2017

Revised: 22 May 2018 - Accepted: 25 May 2018 - Published: 20 June 2018

\begin{abstract}
Measuring the chemical composition of airborne particulate matter (PM) can provide valuable information on the concentration of regulated toxic metals, support modelling approaches for source detection and assist in the identification and validation of abatement techniques. Undertaking these at a high time resolution ( $1 \mathrm{~h}$ or less) enables receptor modelling techniques to be more robustly linked to emission processes. This study describes a comprehensive laboratory and field evaluation of a high time resolution $\mathrm{x}$-ray fluorescence (XRF) instrument (CES XACT 625) for a range of elements (As, $\mathrm{Ba}, \mathrm{Ca}, \mathrm{Cd}, \mathrm{Ce}, \mathrm{Cl}, \mathrm{Cr}, \mathrm{Cu}, \mathrm{Fe}, \mathrm{K}, \mathrm{Mn}, \mathrm{Mo}, \mathrm{Ni}$, $\mathrm{Pb}, \mathrm{Pt}, \mathrm{S}, \mathrm{Sb}, \mathrm{Se}, \mathrm{Si}, \mathrm{Sr}, \mathrm{Ti}, \mathrm{V}$ and $\mathrm{Zn}$ ) against alternative techniques: high time resolution mass measurements, high time resolution ion chromatography, aerosol mass spectrometry, and established filter-based, laboratory analysis using inductively coupled plasma mass spectrometry (ICP-MS).
\end{abstract}

1. Laboratory evaluation was carried out using a novel mass-based calibration technique to independently assess the accuracy of the XRF against laboratory generated aerosols, which resulted in slopes that were not significantly different from unity. This demonstrated that generated particles can serve as an alternative calibration method for this instrument.
2. The XACT was evaluated in three contrasting field deployments; a heavily trafficked roadside site $\left(\mathrm{PM}_{10}\right.$ and $\mathrm{PM}_{2.5}$ ), an industrial location downwind of a nickel refinery $\left(\mathrm{PM}_{10}\right)$ and an urban background location influenced by nearby industries and motorways $\left(\mathrm{PM}_{10}\right)$. The XRF technique agreed well with the ICP-MS measurements of daily filter samples in all cases with a median $R^{2}$ of 0.93 and a median slope of 1.07 for the elements As, Ba, Ca, Cr, Cu, Fe, K, Mn, Ni, Pb, Se, Sr, Ti, V and $\mathrm{Zn}$. Differences in the results were attributed to a combination of inlet location and sampling temperature, variable blank levels in filter paper and recovery rates from acid digestion. The XRF technique also agreed well with the other high time resolution measurements but showed a clear positive difference (slopes between 1.41 and 4.6), probably due to differences in the size selection methodology, volatility and water solubility of the PM in aerosol mass spectrometry $\left(\mathrm{SO}_{4}\right)$ and ion chromatography $\left(\mathrm{Ca}, \mathrm{Cl}, \mathrm{K}\right.$ and $\left.\mathrm{SO}_{4}\right)$, respectively.

3. A novel filter analysis technique using the XACT showed promising initial results: filters analysed offline with the XACT compared well to in situ XACT measurements with a median $R^{2}$ of 0.96 and median slope of 1.07. The resulting range of slopes was com- 
parable to slopes produced in the ICP-MS comparison. This technique provides an opportunity to use the $\mathrm{XACT}$ when it is not deployed in the field; thus expanding the potential use of this instrument in future studies.

\section{Introduction}

It has long been known that increased air pollution, specifically particle pollution, is associated with adverse health effects (Brunekreef and Holgate, 2002; Kelly et al., 2012). Particulate matter (PM) also affects atmospheric visibility and radiative forcing (Fuzzi et al., 2015). PM is not a homogenous air pollutant but rather a complex mixture; it varies in chemical and physical composition depending on the contributing sources and the atmospheric processes (AQEG, 2005). The composition of PM influences its harmfulness and therefore it is important to gain better knowledge about which chemical components might cause particle toxicity (Kelly and Fussell, 2015). Understanding the chemical composition of PM also provides information on the sources and thus helps implement policies on targeting these emission sources (WHO, 2013). Trace metals in particular, even though they do not contribute substantially to the mass of PM, act as markers for specific source categories (Visser et al., 2015a) and evidence is emerging that some metals in ambient PM are associated with adverse health effects at concentrations near to current ambient levels (Chen and Lippmann, 2009).

Accurate measurements of the PM composition are important and are mostly carried out by collecting PM on filters using high or low volume filter samplers (e.g. Digitel-DAH80, Partisol 2025) and subsequently digesting and analysing these in a laboratory. These filters are collected over a period of time, usually $24 \mathrm{~h}$ to a week, and then analysed for different components such as metals (Brown et al., 2008), polyaromatic hydrocarbons (Pandey et al., 2011), elemental and organic carbon (Chu, 2004) and inorganic ions (Beccaceci et al., 2015). This approach is time consuming, labour intensive and prone to positive and negative sampling artefacts for some components (Chow et al., 2015). Also, it only gives compositional information with a considerable time delay and at low temporal resolution which cannot be effectively associated with meteorological variability or short term variations in emissions.

To run the above filter samplers on a higher time resolution means they become even more labour intensive to operate. To address this limitation, sampling devices were developed to collect PM either hourly or sub-hourly without the need for frequent filter changes. These include the rotating drum impactor (Bukowiecki et al., 2005), which collects three size ranges: $\mathrm{PM}_{10-2.5}$ (coarse), $\mathrm{PM}_{2.5-1.0}$ (intermediate) and $\mathrm{PM}_{1.0-0.3}$ (fine), by passing sequentially through three rectangular nozzles of decreasing size; and the Streaker
(PIXE International Corporation) which consists of two collecting substrates rotating at constant speed producing a circular continuous deposition of both $\mathrm{PM}_{10-2.5}$ and $\mathrm{PM}_{2.5}$ (Formenti et al., 1996). Nevertheless the analysis is still performed in the laboratory and thus does not improve the time delay of the analysis.

Several online high time resolution instruments have also been developed in recent years which address some of the sampling artefact, resource and time resolution limitations of laboratory approaches. These include aerosol mass spectrometers such as the ACSM (Aerodyne Research Inc.) $(\mathrm{Ng}$ et al., 2011); ion chromatography approaches such as the MARGA (Metrohm) (Rumsey et al., 2014), PILS (Brechtel) (Weber et al., 2001) and URG's 9000 ambient ion monitor (Beccaceci et al., 2015); and x-ray fluorescence (XRF) such as the XACT instrument (Cooper Environmental Services) (Park et al., 2014). However, these high time resolution instruments only measure a subset of chemical components each, depending on their collection, extraction and analysis methodology. Therefore multiple co-located instruments are needed to measure the full PM composition. Furthermore, the high time resolution instruments tend to measure a narrower range of components with a higher limit of detection (LOD) than equivalent laboratory based methods, generally because less material is collected on each sample. For example, the synchrotron radiation-induced XRF (SRXRF) used by Visser et al. (2015b) measured elements with atomic numbers greater than 11 while the XACT measures elements with atomic numbers greater than 14 thereby missing important contributors to $\mathrm{PM}$ mass such as $\mathrm{Na}, \mathrm{Mg}$ and $\mathrm{Al}$; the LODs reported for the SR-XRF analysis (Visser et al., 2015b) are generally lower than those for the XACT (Furger et al., 2017; Park et al., 2014).

Despite these limitations, the XACT is unique in measuring elements automatically using energy dispersive XRF (ED-XRF) and has been successfully evaluated in a number of field studies (Furger et al., 2017; Park et al., 2014; US-EPA, 2012). In a verification test carried out by the USEPA (2012) measurements of $\mathrm{Ca}, \mathrm{Cu}, \mathrm{Mn}, \mathrm{Pb}, \mathrm{Se}$ and $\mathrm{Zn}$ by the XACT were compared to filter based measurements (filters analysed using ICP-MS). This verification test showed that the daily average XACT 625 results were highly correlated and in close quantitative agreement with ICP-MS analysis results for the six metals, except $\mathrm{Cu}$, which was close to the detection limit of the ICP-MS analysis and the quantitation limit of the XACT 625. Park et al. (2014) found a good agreement between the XACT and $24 \mathrm{~h}$ filters collected in South Korea (filters analysed using ED-XRF). Furger et al. (2017) tested the XACT during a summer campaign in Switzerland in 2015 and compared the XACT data with measurements made using ICP-OES (inductively coupled plasma optical emission spectrometry), ICP-MS and gold amalgamation atomic absorption spectrometry on filters sampled for $24 \mathrm{~h}$ (both $\left.\mathrm{PM}_{10}\right)$ as well as ACSM measurements $\left(\mathrm{PM}_{1}\right)$. They found an excellent correlation, with $R^{2}$ values $\geq 0.95$, 
between the XACT and ICP-MS data for 10 elements $(\mathrm{S}, \mathrm{K}$, $\mathrm{Ca}, \mathrm{Ti}, \mathrm{Mn}, \mathrm{Fe}, \mathrm{Cu}, \mathrm{Zn}, \mathrm{Ba}$ and $\mathrm{Pb}$ ). However, they found that the XACT was systematically higher than the filter based technique. In Jeong et al. (2017) hourly trace elements measured by the XACT were included in positive matrix factorisation (PMF), which allowed a more robust apportionment of PM sources (Jeong et al., 2017).

For all analytical techniques, in the field and laboratory, the confidence in measurements largely depends on high quality, traceable calibration of the instruments (Indresand et al., 2013). In the case of the XACT, the calibration is carried out using thin film standards, which are thin element films deposited on Nuclepore substrates and are available for elements between atomic number 11 and 82 (EPA Compendium Method IO-3.3 for the Determination of Inorganic Compounds in Ambient Air, EPA/625/R-96/010a, Table 2, p. 3.3-16). This is an established method but has been reported to have various limitations (Indresand et al., 2013): the standards are much higher in concentration than most ambient samples; the element mix of the standard might not be representative of ambient particle mix; and the collection properties on a filter may also differ. Alternative calibration methods have therefore been tested to address these issues. For example Indresand et al. (2013) produced sulfur reference materials that replicated PM samples to successfully calibrate XRF systems.

In this study a novel mass-based calibration technique for the XACT 625 has been developed to independently assess the accuracy of the XRF method for a range of elements at more atmospherically relevant concentrations. This study also reports the field evaluation of the XACT at both traffic and industrial sites in the UK where it was compared to independent measurements of $\mathrm{PM}_{2.5}$ and $\mathrm{PM}_{10}$ on daily filters, analysed by ICP-MS, and also to alternative high time resolution chemical speciation instruments (ion chromatography and aerosol mass spectrometry). Additionally, the ability of the XACT to analyse $\mathrm{PM}_{10}$ filter samples in the laboratory was piloted and the results compared to co-located in situ XACT measurements. Using the instrument in this way potentially diversifies experimental sampling programmes with this single resource by deploying additional sampling devices.

\section{Materials and methods}

\subsection{XACT 625}

The instrument measures 24 elements between Silicon and Uranium at a time resolution between $15 \mathrm{~min}$ and $4 \mathrm{~h}$ using ED-XRF. The size fraction of the PM sample collected onto the Teflon filter tape depends on the size selective inlet chosen. The instrument samples with a volumetric flow rate of $1 \mathrm{~m}^{3} \mathrm{~h}^{-1}$ through an inlet tube heated to $45^{\circ} \mathrm{C}$ when the ambient relative humidity $(\mathrm{RH})$ exceeds $45 \%$ to avoid

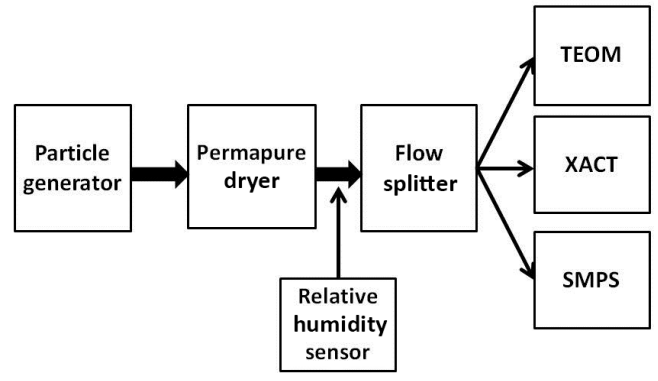

Figure 1. Schematic of instrument set up during laboratory calibration.

water depositing on the tape. Sampling and analysis is performed continuously and simultaneously, except for the time required to advance the filter tape $(\sim 20 \mathrm{~s})$ from the sample to the analysis position. During the analysis, the sample is excited using an x-ray source (Rhodium anode, $50 \mathrm{kV}, 50 \mathrm{Watt}$ ) in three successive energy conditions, which target three different suites of elements. The resulting X-ray fluorescence is measured with a silicon drift detector and the spectra are analysed using a proprietary spectral analysis package which takes into account all peaks associated with a given element. Daily automated quality assurance checks are performed every night at midnight and consist of an energy alignment (an energy calibration using a copper rod, inserted into the analysis area); an upscale measurement to monitor the stability of the instrument response (for $\mathrm{Cd}, \mathrm{Cr}$ and $\mathrm{Pb}$ ); and a flow check through an independent mass flow sensor. Additional quality assurance checks employed here included flow calibrations, regular external standard checks, field blanks performed using a HEPA filter as well as tape blanks before and after each tape change.

For the field studies the instrument sampled $\mathrm{PM}_{10}$ or $\mathrm{PM}_{2.5}$ as detailed below (see Sect. 2.3.1). The elements measured are $\mathrm{As}, \mathrm{Ba}, \mathrm{Ca}, \mathrm{Cd}, \mathrm{Ce}, \mathrm{Cl}, \mathrm{Cr}, \mathrm{Cu}, \mathrm{Fe}, \mathrm{K}, \mathrm{Mn}, \mathrm{Mo}, \mathrm{Ni}$, $\mathrm{Pb}, \mathrm{Pt}, \mathrm{S}, \mathrm{Sb}, \mathrm{Se}, \mathrm{Si}, \mathrm{Sr}, \mathrm{Ti}, \mathrm{V}$ and $\mathrm{Zn}$ and were chosen to represent a range of source categories (i.e. regulatory, traffic, industry), plus the internal palladium (Pd) standard. The internal standard measurement is the reported response from a $\mathrm{Pd}$ rod inserted in a fixed position under the filter tape.

\subsection{Laboratory experiments}

An independent mass-based calibration technique was developed for the XACT. This used laboratory generated aerosols and a schematic of the instrument set-up is shown in Fig. 1. Ammonium sulfate $\left(\left(\mathrm{NH}_{4}\right)_{2} \mathrm{SO}_{4}, \mathrm{ACS}\right.$ reagent grade, Sigma-Aldrich), potassium chloride $(\mathrm{KCl}$, analytical grade, VWR Chemicals) and zinc acetate $\left(\mathrm{Zn}\left(\mathrm{O}_{2} \mathrm{CCH}_{3}\right)_{2}\right.$, analytical grade, VWR Chemicals) were dissolved in high purity water $\left(18.2 \mathrm{M} \Omega\right.$, TOC $<5 \mu \mathrm{g} \mathrm{L}^{-1}$, PURELAB ${ }^{\circledR}$ Ultra Analytic, ELGA, Veolia Water Technologies) to obtain a range of standard solutions spanning the ambient concentration range. 
Table 1. Overview of sites and instrumentation used.

\begin{tabular}{|c|c|c|c|c|}
\hline & \multicolumn{2}{|c|}{ Marylebone Road, London } & \multirow{2}{*}{$\begin{array}{l}\text { Tawe Terrace, Pontardawe } \\
\mathrm{PM}_{10}\end{array}$} & \multirow{2}{*}{$\begin{array}{l}\text { Tinsley, Sheffield } \\
\mathrm{PM}_{10}\end{array}$} \\
\hline & $\mathrm{PM}_{10}$ & $\mathrm{PM}_{2.5}$ & & \\
\hline \multirow{2}{*}{ XACT } & $1 \mathrm{Jul} 2014$ to & 15 Oct 2014 to & 25 Nov 2015 to & 19 Jan 2017 to \\
\hline & 11 Mar 2015 & 1 Dec 2014 & 24 Dec 2015 & 27 Mar 2017 \\
\hline $\operatorname{ACSM}\left(\mathrm{PM}_{1}\right)$ & NA & $\begin{array}{l}15 \text { Oct } 2014 \text { to } \\
1 \text { Dec } 2014\end{array}$ & NA & NA \\
\hline URG & $\begin{array}{l}7 \text { Jan } 2015 \text { to } \\
11 \text { Mar } 2015\end{array}$ & NA & NA & NA \\
\hline \multirow{2}{*}{ Partisol } & \multirow[t]{2}{*}{ NA } & 15 Oct 2014 to & 25 Nov 2015 to & $\begin{array}{l}19 \text { Jan } 2017 \text { to } \\
27 \text { Mar } 2017^{\mathrm{b}}\end{array}$ \\
\hline & & 1 Dec $2014^{\mathrm{a}}$ & $24 \operatorname{Dec} 2015^{b}$ & $\begin{array}{l}17 \text { Feb } 2017 \text { to } \\
10 \text { Mar } 2017^{c}\end{array}$ \\
\hline
\end{tabular}

Filters were digested using ${ }^{\mathrm{a}} \mathrm{HF} / \mathrm{HClO}_{4}$ and ${ }^{\mathrm{b}} \mathrm{HNO}_{3} / \mathrm{H}_{2} \mathrm{O}_{2}$

${ }^{\mathrm{c}}$ Filters were analysed using the XACT in off-line mode.

Table 2. Maximum concentration in field campaigns $\left(\mathrm{ng} \mathrm{m}^{-3}\right)$ and highest and lowest concentration used in calibration test.

\begin{tabular}{lrrrr}
\hline & \multicolumn{4}{c}{ Concentration $\left(\mathrm{ng} \mathrm{m}^{-3}\right)$} \\
\cline { 2 - 5 } Field campaign & $\mathrm{S}$ & $\mathrm{Cl}$ & $\mathrm{K}$ & $\mathrm{Zn}$ \\
\hline London kerbsite $\left(\mathrm{PM}_{10}\right)$ & 3700 & 22000 & 470 & 310 \\
London kerbsite $\left(\mathrm{PM}_{2.5}\right)$ & 3500 & 4600 & 4000 & 370 \\
Wales industrial $\left(\mathrm{PM}_{10}\right)$ & 8900 & 21000 & 1500 & 5500 \\
Sheffield industrial $\left(\mathrm{PM}_{10}\right)$ & 4900 & 10000 & 1020 & 4900 \\
\hline Lowest standard & 2400 & 7200 & 8500 & 4900 \\
Highest standard & 30000 & 35000 & 39000 & 20000 \\
\hline
\end{tabular}

Aerosols were generated using an ATM 226 - Clean Room Aerosol Generator (Topas) and were driven through two Permapure $^{\mathrm{TM}}$ driers set in reflux method to reduce the relative humidity to approximately $40 \%$. The flow was then split isokinetically using a TSI 3708 flow splitter and passed to three instruments: a tapered element oscillating microbalance (1400ab TEOM, Thermo), with which continuous direct mass measurements of particulates were taken; a scanning mobility particle sizer (TSI SMPS 3080); and the XACT. HEPA filtered make-up air was provided where necessary. The mass concentration of the deposited $\left(\mathrm{NH}_{4}\right)_{2} \mathrm{SO}_{4}, \mathrm{KCl}$ and $\mathrm{Zn}\left(\mathrm{O}_{2} \mathrm{CCH}_{3}\right)_{2}$ as measured by the TEOM were used to calculate the $\mathrm{S}, \mathrm{Cl}, \mathrm{K}$ and $\mathrm{Zn}$ mass concentrations and compared to the element concentration measured with the XACT. The SMPS was used to give qualitative diagnostic information on the size distribution of the aerosol.

\subsection{Field experiments}

\subsubsection{Monitoring locations}

Three field evaluation campaigns were carried out in the UK (Table 1): a traffic site in central London (Marylebone Road: $51^{\circ} 31^{\prime} 21^{\prime \prime} \mathrm{N}, 0^{\circ} 09^{\prime} 17^{\prime \prime} \mathrm{W}$ ) and two industrial sites (Pontardawe in Wales: $51^{\circ} 43^{\prime} 12^{\prime \prime} \mathrm{N}, 3^{\circ} 50^{\prime} 49^{\prime \prime} \mathrm{W}$; and Tinsley in Sheffield: $53^{\circ} 24^{\prime} 38^{\prime \prime} \mathrm{N}, 1^{\circ} 23^{\prime} 46^{\prime \prime} \mathrm{W}$ ) (map in Supplement S1). Marylebone Road is a kerbside monitoring station in a central London street canyon adjacent to a six lane highway (60-80 000 vehicles day ${ }^{-1}$ ). During this deployment the XACT sampled $\mathrm{PM}_{10}$ except for a period from October to December 2014 that sampled $\mathrm{PM}_{2.5}$. Pontardawe is an urban industrial site in South Wales, surrounded by metallurgical industries. Tinsley, located north-east of Sheffield, is approximately $200 \mathrm{~m}$ east of the M1 motorway, with a residential area to the east and light industry to the west. In Pontardawe and Tinsley, the XACT was co-located with the monitoring site belonging to the UK Ambient Air Quality Metals Monitoring Network from which daily filters measured by ICPMS were available.

\subsubsection{Comparison instruments}

A number of comparison instruments were used to evaluate the XACT in the field. The main comparison was carried out using filter samples collected with a Partisol 2025 and subsequent ICP-MS analysis. Further, an Aerosol Chemical Speciation Monitor (ACSM) and Ambient Ion MonitorURG-900B (URG) were used for the evaluation of XACT at a high time resolution. Although the measurands are not directly comparable, they provide useful information for studies where source contributions may be estimated by recep- 
tor modelling using measurements of chemical components based on one of these measurement techniques.

\section{Partisol 2025}

A Thermo Scientific Partisol 2025, with a flow rate of $1 \mathrm{~m}^{3} \mathrm{~h}^{-1}$, was used to collect filter samples (mixed cellulose ester filters, VWR 514-0464) for subsequent analysis using ICP-MS. At Marylebone Road, where samples were taken specifically for this study, a $23 \mathrm{~h}$ sampling period was used (01:00-00:00 UTC) to ensure comparability with the XACT once the equivalent hour lost to quality assurance was removed. The filters were acid-digested on a hotplate using a $1: 2$ mixture of $\mathrm{HClO}_{4}$ and $\mathrm{HF}$ in open $10 \mathrm{ml}$ Teflon crucibles. After complete evaporation, $\mathrm{HNO}_{3}$ has been added to each sample, and the remaining solution was made up to the required volume. Filters were fully dissolved with this method (adapted from ISO-14869-1:2001). For quality assurance, blank filters (field and laboratory blanks), internal (rhyolite) and international (NIST SRM 1648a) certified reference materials were also prepared following the same procedure. The samples were analysed for a range of elements using ICP-MS (Table 3).

At Pontardawe and Tinsley, where an established measurement programme was adapted for comparison, a $24 \mathrm{~h}$ period was sampled. Thus the frequency of $\mathrm{PM}_{10}$ filter sampling at the adjacent UK Heavy Metals Network sites was increased from weekly to daily for these field evaluations. The filters were digested using $\mathrm{HNO}_{3} / \mathrm{H}_{2} \mathrm{O}_{2}$ digestion following the European reference method EN14902 and analysed for a range of elements (Tables 4 and 5) using ICP-MS (Goddard et al., 2016).

The certified reference material was used for quality control in both filter digestion protocols. As standard reference materials are usually not an exact match for the matrix of the sample, the resulting recovery rates serve as a quality control parameter rather than a calibrant. Samples were thus not corrected for the recovery rate but checked for compliance with the requirements described in EN14902; recovery rates for both digestions methods are given in Supplement S5.

\section{Aerosol Chemical Speciation Monitor (ACSM)}

The ACSM measured the chemical composition of nonrefractory $\mathrm{PM}_{1}\left(\mathrm{NO}_{3}, \mathrm{SO}_{4}, \mathrm{NH}_{4}\right.$ and organic mass) and is fully described in $\mathrm{Ng}$ et al. (2011). Briefly, air was drawn through an URG $\mathrm{PM}_{2.5}$ size selective inlet (URG2000-30EQ) at $0.18 \mathrm{~m}^{3} \mathrm{~h}^{-1}$ and subsequently dried using a Permapure $^{\mathrm{TM}}$ drier (Perma Pure PD Dryer, PD-07018T12MSS). Particles were focused using an aerodynamic lens with a $50 \%$ transmission range of 75 to $650 \mathrm{~nm}$ (Liu et al., 2007) and subsequently flash vaporised, ionised and analysed using mass spectrometry at 0 to $100 \mathrm{amu}$. The signal was resolved into $\mathrm{NO}_{3}, \mathrm{SO}_{4}, \mathrm{NH}_{4}$ and organic mass using a library of known fragmentation characteristics. The aerosol was sampled and analysed alternately with background air, allowing a continuous air subtraction, and averaged to an hourly time resolution. The ionisation efficiency of nitrate and the relative ionisation efficiencies of ammonium and sulfate were calculated using a mono-disperse supply of ammonium nitrate and ammonium sulfate aerosols. These were size selected through a differential mobility analyser and counted using a condensation particle counter (CPC) as described by Crenn et al. (2015). The collection efficiency was calculated using the Middlebrook parameterisation (Middlebrook et al., 2012), which calculates an optimum collection based on aerosol acidity, inlet humidity and particle composition. The ACSM measurements were combined with Aethalometer measurements $\left(\mathrm{PM}_{2.5}\right)$ and compared to $\mathrm{PM}_{2.5}$ mass measured using the TEOM FDMS or $\mathrm{PM}_{1}$ mass estimated using SMPS measurements as described by Crenn et al. (2015).

\section{Ambient Ion Monitor- URG-900B (URG)}

The URG-900B Ambient Ion Monitor continuously measured water-soluble anion and cation concentrations $\left(\mathrm{Cl}^{-}\right.$, $\mathrm{SO}_{4}^{2-}, \mathrm{NO}_{3}^{-}, \mathrm{Na}^{+}, \mathrm{NH}_{4}^{+}, \mathrm{K}^{+}, \mathrm{Mg}^{2+}$, and $\left.\mathrm{Ca}^{2+}\right)$ in $\mathrm{PM}_{10}$ and is described in Beccaceci et al. (2015). Briefly, the sample was drawn at a flow rate of $1 \mathrm{~m}^{3} \mathrm{~h}^{-1}$ through a size selective inlet $\left(\mathrm{PM}_{10}\right)$; the sample was then split isokinetically through a flow splitter to allow a $0.18 \mathrm{~m}^{3} \mathrm{~h}^{-1}$ flow into a liquid diffusion denuder containing $\mathrm{H}_{2} \mathrm{O}_{2}$ to remove interfering acidic and basic gases. The remaining particles in this air stream were then enlarged in a super saturation chamber and finally collected in an aerosol sample collector and injected into the (anion and cation) ion chromatographs every hour.

\subsection{Laboratory based filter analysis using the XACT}

To trial a filter analysis technique using the XACT, $\mathrm{PM}_{10}$ was sampled onto polytetrafluoroethylene (PTFE) filters (Zefluor, $0.5 \mu \mathrm{m}, 47 \mathrm{~mm}$ disc, Pall Life Sciences 516-8908) for $24 \mathrm{~h}$ using a Partisol 2025 during the field campaign in Sheffield in February and March 2017. These PTFE filters were a similar material to the XACT filter tape but the stronger structure enables easier handling during punching and analysis. After exposure a $25 \mathrm{~mm}$ punch was taken out of the exposed filters for analysis with the XACT on its return to the laboratory. The punching tool was always aligned with the edge of the exposed area. The punch was transferred into a filter holder, identical to the one used for instrument calibration with thin film standards, and transferred into the holder slot in the analysis block of the XACT. The analysis was performed on a 15 min sample time using the XRF control program in a manual analysis mode. The energy condition set up remained the same as during the field sampling in the automation mode. Each filter was analysed four times, and the filter punch was rotated $90^{\circ}$ in the filter holder in between replicates in order to account for non-uniformity of the particle deposit on the 
Table 3. Overview of Marylebone Road, London measurements by XACT and ICP-MS $\left(\mathrm{ng} \mathrm{m}^{-3}\right)$. The asterisk $\left(^{*}\right)$ denotes that only 18 samples were collected for XACT As).

\begin{tabular}{|c|c|c|c|c|c|c|c|c|c|c|c|c|c|}
\hline & \multicolumn{7}{|c|}{ XACT $\left(\mathrm{ng} \mathrm{m}^{-3}\right)$} & \multicolumn{6}{|c|}{$\mathrm{ICP} / \mathrm{MS}\left(\mathrm{ng} \mathrm{m}^{-3}\right)$} \\
\hline & Species & Mean & SD & med & Min & Max & LOD & Mean & SD & Med & Min & Max & LOD \\
\hline \multirow{22}{*}{ 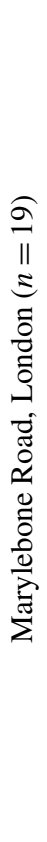 } & As* & 1.51 & 2.4 & 0.40 & 0.001 & 8.8 & 0.00020 & 0.97 & 1.02 & 0.53 & 0.049 & 4.0 & 0.099 \\
\hline & $\mathrm{Ba}$ & 15.8 & 14.3 & 10.0 & 1.74 & 50 & 0.31 & 15.1 & 9.9 & 11.0 & 3.1 & 39 & 0.0166 \\
\hline & $\mathrm{Ca}$ & 67 & 35 & 61 & 19.5 & 157 & 1.11 & 71 & 32 & 65 & 23 & 142 & 0.0166 \\
\hline & $\mathrm{Cd}$ & 4.0 & 0.37 & 4.0 & 3.4 & 4.7 & 2.4 & 0.114 & 0.106 & 0.079 & 0.023 & 0.39 & 0.0046 \\
\hline & $\mathrm{Ce}$ & 1.07 & 0.198 & 1.09 & 0.61 & 1.42 & 0.135 & 0.38 & 0.128 & 0.36 & 0.182 & 0.62 & 0.00030 \\
\hline & $\mathrm{Cl}$ & 400 & 400 & 250 & 4.4 & 1180 & 2.1 & & & & & & \\
\hline & $\mathrm{Cr}$ & 1.33 & 0.52 & 1.35 & 0.46 & 2.4 & 0.025 & & & & & & \\
\hline & $\mathrm{Cu}$ & 21 & 7.3 & 21 & 6.5 & 35 & 0.29 & 16.5 & 6.6 & 14 & 3.7 & 29 & 0.187 \\
\hline & $\mathrm{Fe}$ & 470 & 124 & 450 & 240 & 710 & 5.4 & 380 & 90 & 360 & 230 & 600 & 1.52 \\
\hline & $\mathrm{K}$ & 230 & 230 & 103 & 59 & 870 & 7.9 & 230 & 230 & 110 & 48 & 890 & 8.1 \\
\hline & $\mathrm{Mn}$ & 4.9 & 1.32 & 4.6 & 3.0 & 8.1 & 0.076 & 3.9 & 1.33 & 3.8 & 1.91 & 7.3 & 0.045 \\
\hline & Mo & 0.64 & 0.109 & 0.62 & 0.46 & 0.97 & 0.40 & & & & & & \\
\hline & $\mathrm{Ni}$ & 0.73 & 0.60 & 0.54 & 0.25 & 2.2 & 0.099 & 1.33 & 0.74 & 1.14 & 0.50 & 2.8 & 0.0044 \\
\hline & $\mathrm{Pb}$ & 11.1 & 8.7 & 7.7 & 1.66 & 31 & 0.116 & 8.1 & 7.2 & 5.1 & 1.10 & 25 & 0.093 \\
\hline & $\mathrm{Pt}$ & 0.177 & 0.010 & 0.175 & 0.161 & 0.20 & 0.078 & & & & & & \\
\hline & $S$ & 600 & 330 & 460 & 180 & 1600 & 3.3 & & & & & & \\
\hline & $\mathrm{Se}$ & 0.177 & 0.169 & 0.112 & 0.070 & 0.77 & 0.031 & & & & & & \\
\hline & $\mathrm{Si}$ & 110 & 70 & 85 & 72 & 340 & 65 & & & & & & \\
\hline & $\mathrm{Sr}$ & 3.8 & 5.8 & 0.95 & 0.47 & 19 & 0.25 & 2.9 & 4.3 & 0.93 & 0.106 & 14.6 & 0.026 \\
\hline & $\mathrm{Ti}$ & 4.4 & 2.7 & 3.4 & 1.80 & 12 & 0.158 & 2.9 & 2.5 & 1.97 & 0.28 & 9.1 & 0.067 \\
\hline & $\mathrm{V}$ & 0.84 & 0.81 & 0.67 & 0.138 & 2.7 & 0.085 & & & & & & \\
\hline & $\mathrm{Zn}$ & 27 & 16 & 21 & 5.2 & 57 & 0.195 & 22 & 10.9 & 17.7 & 7.5 & 39 & 1.43 \\
\hline
\end{tabular}

Table 4. Overview of Pontardawe, Wales measurements by XACT and ICP-MS (ng m ${ }^{-3}$ ).

\begin{tabular}{|c|c|c|c|c|c|c|c|c|c|c|c|c|c|}
\hline & \multicolumn{7}{|c|}{ XACT $\left(\mathrm{ng} \mathrm{m}^{-3}\right)$} & \multicolumn{6}{|c|}{ ICP / MS $\left(\mathrm{ng} \mathrm{m}^{-3}\right)$} \\
\hline & Species & Mean & SD & Med & Min & Max & LOD & Mean & SD & Med & Min & Max & LOD \\
\hline \multirow{22}{*}{ 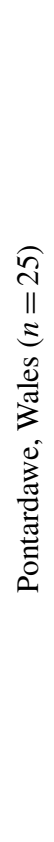 } & As & 0.43 & 0.47 & 0.22 & 0.037 & 2.2 & 0.00020 & 0.23 & 0.31 & 0.081 & 0.030 & 1.12 & 0.037 \\
\hline & $\mathrm{Ba}$ & 1.41 & 0.63 & 1.10 & 0.97 & 3.1 & 0.31 & & & & & & \\
\hline & $\mathrm{Ca}$ & 191 & 109 & 155 & 50 & 510 & 1.11 & & & & & & \\
\hline & $\mathrm{Cd}$ & 3.0 & 0.35 & 2.9 & 2.5 & 3.8 & 2.4 & 0.085 & 0.080 & 0.068 & 0.004 & 0.31 & 0.0110 \\
\hline & $\mathrm{Ce}$ & 0.85 & 0.30 & 0.76 & 0.46 & 1.95 & 0.135 & & & & & & \\
\hline & $\mathrm{Cl}$ & 5200 & 3000 & 5000 & 330 & 12700 & 2.1 & & & & & & \\
\hline & $\mathrm{Cr}$ & 1.62 & 2.4 & 0.41 & 0.065 & 9.8 & 0.025 & 1.52 & 0.81 & 1.26 & 1.26 & 4.8 & 1.43 \\
\hline & $\mathrm{Cu}$ & 3.8 & 2.2 & 3.9 & 0.67 & 8.9 & 0.29 & 4.0 & 2.2 & 3.7 & 0.63 & 9.1 & 0.099 \\
\hline & $\mathrm{Fe}$ & 230 & 196 & 154 & 28 & 780 & 5.4 & 210 & 168 & 183 & 41 & 700 & 6.0 \\
\hline & $\mathrm{K}$ & 154 & 60 & 138 & 83 & 340 & 7.9 & & & & & & \\
\hline & $\mathrm{Mn}$ & 3.1 & 2.7 & 2.3 & 0.55 & 11.0 & 0.076 & 2.7 & 2.5 & 2.1 & 0.180 & 9.9 & 0.071 \\
\hline & Mo & 1.15 & 2.1 & 0.58 & 0.45 & 10.2 & 0.40 & & & & & & \\
\hline & $\mathrm{Ni}$ & 20 & 64 & 2.5 & 0.24 & 320 & 0.099 & 21 & 58 & 3.0 & 0.192 & 290 & 0.54 \\
\hline & $\mathrm{Pb}$ & 3.7 & 4.3 & 2.6 & 0.29 & 21 & 0.12 & 2.9 & 3.5 & 1.99 & 0.140 & 16.6 & 0.22 \\
\hline & $\mathrm{Pt}$ & 0.30 & 0.47 & 0.189 & 0.162 & 2.5 & 0.078 & & & & & & \\
\hline & $\mathrm{S}$ & 530 & 240 & 450 & 196 & 1130 & 3.3 & & & & & & \\
\hline & $\mathrm{Se}$ & 0.24 & 0.164 & 0.197 & 0.096 & 0.88 & 0.031 & 1.34 & 0.37 & 1.32 & 0.73 & 1.92 & 0.190 \\
\hline & $\mathrm{Si}$ & 280 & 420 & 102 & 92 & 1820 & 65 & & & & & & \\
\hline & $\mathrm{Sr}$ & 2.5 & 1.43 & 2.2 & 0.49 & 6.3 & 0.25 & & & & & & \\
\hline & $\mathrm{Ti}$ & 8.7 & 15.4 & 2.8 & 0.61 & 65 & 0.158 & & & & & & \\
\hline & V & 1.11 & 1.29 & 0.45 & 0.159 & 4.3 & 0.085 & 1.10 & 1.18 & 0.62 & 0.094 & 3.9 & 0.0160 \\
\hline & $\mathrm{Zn}$ & 7.3 & 6.9 & 5.3 & 0.69 & 34 & 0.195 & 6.8 & 7.1 & 5.8 & 0.32 & 34 & 0.81 \\
\hline
\end{tabular}


Table 5. Overview of Tinsley, Sheffield measurements by XACT and ICP-MS (ng m ${ }^{-3}$ ).

\begin{tabular}{|c|c|c|c|c|c|c|c|c|c|c|c|c|c|}
\hline & \multicolumn{7}{|c|}{ XACT $\left(\mathrm{ng} \mathrm{m}^{-3}\right)$} & \multicolumn{6}{|c|}{ ICP/MS $\left(\mathrm{ng} \mathrm{m}^{-3}\right)$} \\
\hline & Species & mean & SD & Med & Min & Max & LOD & Mean & SD & Med & Min & Max & LOD \\
\hline \multirow{22}{*}{ 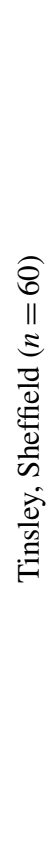 } & As & 2.9 & 4.8 & 1.35 & 0.035 & 33 & 0.00020 & 1.50 & 3.4 & 0.78 & 0.019 & 26 & 0.037 \\
\hline & $\mathrm{Ba}$ & 2.6 & 3.6 & 1.75 & 0.98 & 28 & 0.31 & & & & & & \\
\hline & $\mathrm{Ca}$ & 400 & 260 & 370 & 37 & 1100 & 1.11 & & & & & & \\
\hline & $\mathrm{Cd}$ & 3.4 & 0.57 & 3.3 & 2.7 & 6.6 & 2.4 & 0.80 & 1.64 & 0.32 & 0.035 & 11.7 & 0.0110 \\
\hline & $\mathrm{Ce}$ & 0.76 & 0.22 & 0.73 & 0.41 & 1.52 & 0.135 & & & & & & \\
\hline & $\mathrm{Cl}$ & 1370 & 1100 & 1140 & 36 & 5100 & 2.1 & & & & & & \\
\hline & $\mathrm{Cr}$ & 53 & 65 & 30 & 0.42 & 350 & 0.025 & 55 & 51 & 38 & 3.9 & 250 & 1.43 \\
\hline & $\mathrm{Cu}$ & 17.5 & 11.0 & 14.6 & 2.3 & 47 & 0.29 & 19.3 & 12.5 & 16.0 & 2.6 & 56 & 0.099 \\
\hline & $\mathrm{Fe}$ & 670 & 440 & 570 & 83 & 1950 & 5.4 & 680 & 420 & 580 & 92 & 1600 & 6.0 \\
\hline & $\mathrm{K}$ & 138 & 92 & 108 & 17.0 & 420 & 7.9 & & & & & & \\
\hline & $\mathrm{Mn}$ & 47 & 53 & 32 & 1.58 & 290 & 0.076 & 41 & 44 & 29 & 1.82 & 240 & 0.071 \\
\hline & Mo & 15.1 & 24 & 7.0 & 0.65 & 130 & 0.40 & & & & & & \\
\hline & $\mathrm{Ni}$ & 25 & 29 & 14.0 & 0.22 & 113 & 0.099 & 24 & 26 & 13.8 & 0.99 & 113 & 0.54 \\
\hline & $\mathrm{Pb}$ & 22 & 23 & 13.1 & 1.33 & 125 & 0.116 & 22 & 22 & 11.8 & 1.21 & 111 & 0.22 \\
\hline & $\mathrm{Pt}$ & 0.186 & 0.017 & 0.185 & 0.166 & 0.28 & 0.078 & & & & & & \\
\hline & $\mathrm{S}$ & 780 & 670 & 550 & 126 & 3400 & 3.3 & & & & & & \\
\hline & $\mathrm{Se}$ & 0.93 & 1.30 & 0.31 & 0.075 & 5.5 & 0.031 & 1.83 & 1.62 & 0.94 & 0.26 & 6.2 & 0.190 \\
\hline & $\mathrm{Si}$ & 210 & 150 & 164 & 71 & 780 & 65 & & & & & & \\
\hline & $\mathrm{Sr}$ & 1.15 & 0.68 & 1.10 & 0.41 & 3.6 & 0.25 & & & & & & \\
\hline & $\mathrm{Ti}$ & 23 & 36 & 14.3 & 1.42 & 220 & 0.158 & & & & & & \\
\hline & V & 1.16 & 2.0 & 0.60 & 0.179 & 12.9 & 0.085 & 1.45 & 1.47 & 1.02 & 0.171 & 9.6 & 0.0160 \\
\hline & $\mathrm{Zn}$ & 100 & 120 & 58 & 4.5 & 620 & 0.195 & 101 & 117 & 56 & 3.8 & 610 & 0.81 \\
\hline
\end{tabular}

Table 6. Overview of Marylebone Road, London hourly $\mathrm{SO}_{4}$ measurements in $\mathrm{PM}_{2.5}$ by XACT and ACSM (ng m ${ }^{-3}$ ); and hourly $\mathrm{SO}_{4}, \mathrm{~K}_{\text {, }}$ $\mathrm{Cl}$, Ca measurements in PM10 by XACT and URG $\left(\mathrm{ng} \mathrm{m}^{-3}\right)$; The asterisk $\left(^{*}\right)$ denotes that $\mathrm{SO}_{4}$ was calculated as non-sea salt $\mathrm{SO}_{4}$ using $\mathrm{S}$ and $\mathrm{Cl}$ measurements; the asterisk (**) denotes that $\mathrm{SO}_{4}$ was calculated as predicted $\mathrm{SO}_{4}$ using $\mathrm{S}$ measurements.

\begin{tabular}{|c|c|c|c|c|c|c|c|c|c|c|c|c|c|}
\hline \multirow[b]{2}{*}{ Species } & \multirow[b]{2}{*}{$n$} & \multicolumn{6}{|c|}{ XACT $\left(\mathrm{ng} \mathrm{m}^{-3}\right)$} & \multicolumn{6}{|c|}{$\operatorname{ACSM}\left(\mathrm{ng} \mathrm{m}^{-3}\right)$} \\
\hline & & Mean & SD & Med & Min & Max & LOD & Mean & SD & Med & Min & Max & LOD \\
\hline \multirow[t]{2}{*}{$\mathrm{SO}_{4} *$} & 737 & 2600 & 2200 & 1880 & 240 & 10500 & NA & 2000 & 1700 & 1460 & 58 & 8300 & 35 \\
\hline & & \multicolumn{6}{|c|}{ XACT $\left(\mathrm{ng} \mathrm{m}^{-3}\right)$} & \multicolumn{6}{|c|}{$\operatorname{URG}\left(\mathrm{ng} \mathrm{m}^{-3}\right)$} \\
\hline Species & $n$ & mean & SD & med & $\min$ & $\max$ & LOD & mean & SD & med & $\min$ & $\max$ & LOD \\
\hline $\mathrm{SO}_{4} * *$ & 1045 & 1750 & 1210 & 1450 & 164 & 9000 & NA & 1040 & 810 & 810 & 54 & 6500 & 100 \\
\hline $\mathrm{K}$ & 776 & 145 & 69 & 133 & 24 & 410 & 6.2 & 154 & 42 & 150 & 75 & 380 & 100 \\
\hline $\mathrm{Cl}$ & 1045 & 2700 & 2400 & 2100 & 42 & 22000 & 9 & 1790 & 1530 & 1370 & 132 & 15000 & 100 \\
\hline $\mathrm{Ca}$ & 996 & 590 & 490 & 430 & 49 & 2900 & 3.3 & 440 & 300 & 360 & 97 & 2300 & 100 \\
\hline
\end{tabular}

filter punch. The XACT results were used to calculate daily ambient element concentrations, which were compared to the daily mean concentration measured by the XACT in situ. A total of 12 filters were analysed. For quality assurance field and laboratory filter blanks were analysed and used to correct for the filter background. The blank measurements were also used to calculate the limit of detection for this method.

\subsection{Regression analysis approach}

All comparisons were carried out using the Deming regression which minimises the sum of distances between the regression line and the $X$ and $Y$ variables taking into account the uncertainties in both variables (Deming, 1943). 


\subsection{Treatment of measurements below limit of detection}

In all comparisons data under the detection limit were used as measured unless the value was zero or below, in which case $0.5 *$ LOD was used to replace the value. By including values below the LOD it was possible to calculate daily XACT mean concentrations, which might have been lost if data below the LOD had been excluded and the daily data capture had not been met.

\subsection{Uncertainty evaluation}

The expanded uncertainty, representing a $95 \%$ level of confidence, was calculated by taking the root of sum square of the separate sources of uncertainty as shown below:

$U=\sqrt{\operatorname{LOD}_{i}^{2}+\left(b \cdot c_{i}\right)^{2}}$,

where $\mathrm{LOD}_{i}$ is the limit of detection of element $i$ (here calculated as 3 times the experimental standard deviation of field or laboratory blanks), $c_{i}$ is the measured concentration of the element (in $\mathrm{n} \mathrm{m}^{-3}$ ), and $b$ is an element dependent factor, which was derived from experimental and literature values (US-EPA, 1999). For the XACT measurements, the combined uncertainty included contributions of $\frac{3}{\sqrt{ } 3} \%$ from flow (CEN, 2014), $5 \%$ from calibration standard uncertainty (US-EPA, 1999), $2.9 \%$ from long term stability (calculated from the standard deviation of hourly internal Pd reference) and an element-specific uncertainty associated with the spectral deconvolution calculated by the instrument software for each spectra. The XACT LOD was determined using HEPA field blank measurements during each campaign; these are shown in Table 3. For the ACSM, the sulfate measurement uncertainty was estimated as $14 \%$ (coverage factor $k=2$ ) for sulfate at a $30 \mathrm{~min}$ resolution by Crenn et al. (2015) and the LOD was determined using HEPA field blank measurements as $34.9 \mathrm{ng} \mathrm{m}^{-3}$. For the URG, the chloride and sulfate LODs were reported by the manufacturer as $100 \mathrm{ng} \mathrm{m}^{-3}$ and verified by Beccaceci et al. (2015). The uncertainty of the species measured by ion chromatography was estimated at $4.5 \%$ (coverage factor $k=2$ ) by Yardley et al. (2007) and combined with the additional $97 \%$ extraction efficiency of a particle-to-liquid sampler system estimated by Orsini et al. (2003).

\section{Results and discussion}

\subsection{Laboratory experiment}

For the calibration test a range of solution concentrations were produced to assess the instrument response (see Supplement S2). A subset of concentrations, which span the concentrations encountered during the field campaign, was used for the final comparison (see Table 2). The highest element concentrations in the standards used for comparison were between $9(\mathrm{~S})$ and $25(\mathrm{Zn})$ times lower than the commercial thin film standards when compared as ng.

All calibrations resulted in a linear relationship between the mass calculated using TEOM mass concentrations and measured by the XACT for the standard range used. Sample self absorption effects were calculated to be $<1 \%$ for the maximum concentration of $S$ (the lightest element used) and therefore insignificant in the use of this instrument. All calibrations resulted in a linear relationship between the mass calculated using TEOM mass concentrations and measured by the XACT for the standard range used (Fig.2). TEOM and XACT results agreed well in all cases with slopes between 0.94 and 0.99 . Slopes are not significantly different from the $1: 1$ line for all comparisons (95\% confidence interval). The coefficient of determination $\left(R^{2}\right)$ ranged between $0.98(\mathrm{~S})$ and $0.99(\mathrm{Cl}, \mathrm{K}, \mathrm{Zn})$. The XACT response to the generated particles was thus comparable to the response of the commercial standards used for calibration. A similar result was found by Indresand et al. (2013) using prepared sulfur reference materials for XRF calibration.

\subsection{Field evaluation: overview}

An overview of the data recorded in each comparison is given in Tables 3-6 and includes the limit of detection for all elements. Sb was not included in the analysis as spectral interference resulted in a high LOD.

The sampling at Marylebone Road was carried out using a $\mathrm{PM}_{2.5}$ inlet during a period when peak concentrations were dominated by fireworks activity (October-December 2014). The mean concentrations across all elements measured during this campaign ranged from 0.177 to $600 \mathrm{ng} \mathrm{m}^{-3}$ and elements typically used in fireworks such as $\mathrm{Ba}, \mathrm{Sr}, \mathrm{K}$ and Ti (Godri et al., 2010; Moreno et al., 2007; Vecchi et al., 2008) had high maximum concentrations. Traffic emissions further influenced the metal concentrations at Marylebone Road. Overall the order of the elements in terms of mean concentration was as follows:

$$
\begin{aligned}
\mathrm{S} & >\mathrm{Fe}>\mathrm{Cl}>\mathrm{K}>\mathrm{Si}>\mathrm{Ca}>\mathrm{Zn}>\mathrm{Cu}>\mathrm{Ba}>\mathrm{Pb} \\
& >\mathrm{Mn}>\mathrm{Ti}>\mathrm{Cd}>\mathrm{Sr}>\mathrm{As}>\mathrm{Cr}>\mathrm{Ce}>\mathrm{V} \\
& >\mathrm{Ni}>\mathrm{Mo}>\mathrm{Pt}>\mathrm{Se} .
\end{aligned}
$$

This dataset helps highlight that high time resolution data has the advantage of giving much more detailed information on high pollution events, which can be used e.g. in source apportionment (Vecchi et al., 2008) and for health studies (Godri et al., 2010; Hamad et al., 2016). Figure 3 shows the daily filter and hourly XACT measurements of $\mathrm{K}$ and Ba during a period of increased bonfire and fireworks activity due to Diwali (Hindu festival of light) and Guy Fawkes celebrations. The daily filter measurements show that the highest concentrations of $\mathrm{K}$, which is used as an oxidiser in fireworks (Moreno et al., 2007) but also a tracer for biomass burning, 

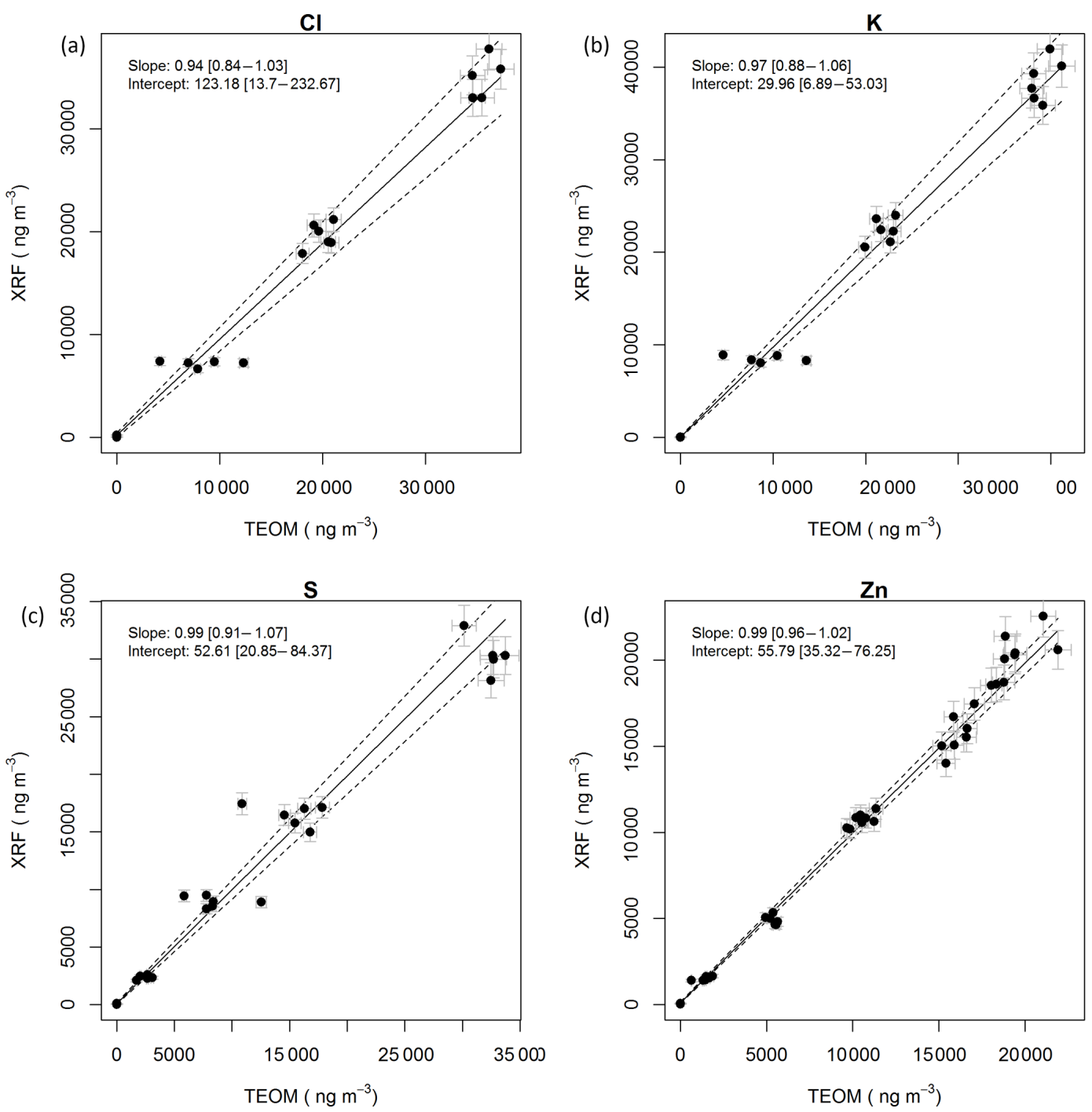

Figure 2. Deming regression of $\mathrm{Cl}(\mathbf{a}), \mathrm{K}(\mathbf{b}), \mathrm{S}(\mathbf{c})$ and $\mathrm{Zn}(\mathbf{d})$ mass concentrations measured with the XACT and calculated from TEOM mass measurements.

were measured on the 5 and 6 November 2014, followed by slightly lower concentrations on the 7 and 8 November. On the other hand $\mathrm{Ba}$, which is used in green fireworks (Moreno et al., 2007), displays similarly high concentrations on all four days. Looking at the $\mathrm{K}$ concentration in a higher time resolution as measured by the XACT, it is evident that peak concentrations were comparable on the nights of the 5,7 and 8 November (data are missing for 6 November due to instrument failure) but the high concentrations did not last as long on 7 and 8 November. The highest $\mathrm{Ba}$ concentration on the other hand was measured on 8 November with lower concentrations on 5 and 7 November. This difference in contribution might point to different fireworks being used.

Sampling at Pontardawe, Wales was carried out in an area dominated by metallurgical industry, which is reflected by the high nickel concentrations measured (i.e. the mean nickel concentration at Pontardawe was 27 times higher than that measured at Marylebone Road). Overall, the mean elemental concentrations measured in this campaign ranged from 0.24 to $5200 \mathrm{ng} \mathrm{m}^{-3}$. The concentrations and dominant elements will be influenced by the site characteristics as well as the size range sampled; e.g. $\mathrm{Cl}$ from sea salt is predominantly found in the coarse fraction and thus much higher at Pontardawe as the sample site is closer to the sea and sampling was carried out using a $\mathrm{PM}_{10}$ head. The order of elements in terms of mean concentration in Wales was as follows:

$$
\begin{aligned}
\mathrm{Cl} & >\mathrm{S}>\mathrm{Si}>\mathrm{Fe}>\mathrm{Ca}>\mathrm{K}>\mathrm{Ni}>\mathrm{Ti}>\mathrm{Zn}>\mathrm{Cu} \\
& >\mathrm{Pb}>\mathrm{Mn}>\mathrm{Cd}>\mathrm{Sr}>\mathrm{Cr}>\mathrm{Ba}>\mathrm{Mo}>\mathrm{V} \\
& >\mathrm{Ce}>\mathrm{As}>\mathrm{Pt}>\mathrm{Se} .
\end{aligned}
$$

In Wales, the availability of high time resolution data, in conjunction with meteorological data and source emission activ- 

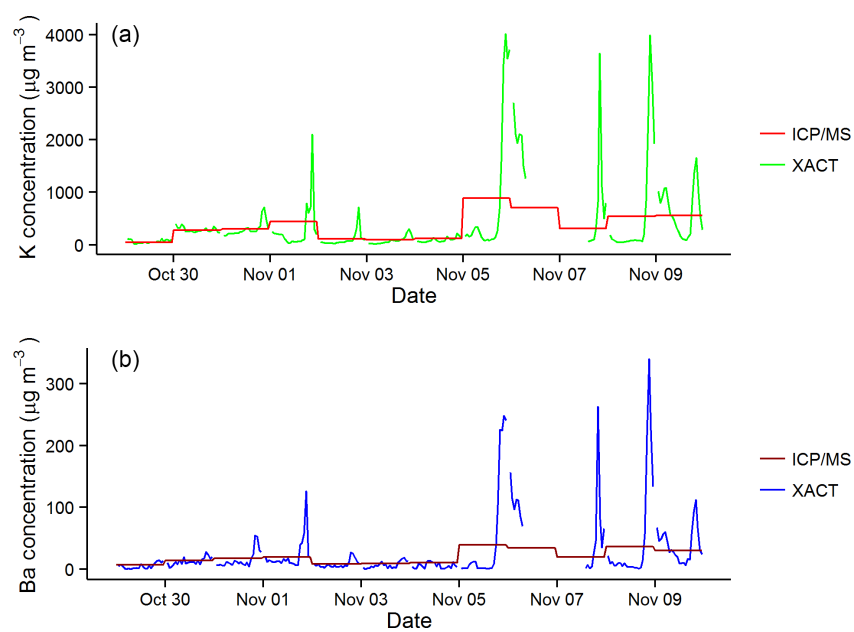

Figure 3. Time series of $\mathrm{K}(\mathbf{a})$ and $\mathrm{Ba}(\mathbf{b})$ concentration $\left(\mu \mathrm{g} \mathrm{m}^{-3}\right)$ using hourly XACT and daily ICP-MS measurements at Marylebone Road, London.

ity allowed us to pinpoint pollution sources more accurately. $\mathrm{Cr}$ concentrations from local sources were studied to identify contributions from different industries. As can be seen in Fig. 4 the $24 \mathrm{~h}$ filter data leads to very different source directions than the higher time resolution data by the XACT (Font et al., 2017). This could be used to address policy breaches with more targeted abatement measures.

The influence of the local industry in Tinsley, Sheffield was reflected by high concentrations of metals like $\mathrm{Ni}$ and $\mathrm{Cr}$, with mean concentrations more than 30 times that found in the Marylebone Road campaign. The mean elemental concentrations overall ranged from 0.186 to $1370 \mathrm{ng} \mathrm{m}^{-3}$. The order of elements in terms of mean concentration in Tinsley was as follows:

$$
\begin{aligned}
\mathrm{Cl} & >\mathrm{S}>\mathrm{Fe}>\mathrm{Ca}>\mathrm{Si}>\mathrm{K}>\mathrm{Zn}>\mathrm{Cr}>\mathrm{Mn}>\mathrm{Ni} \\
& >\mathrm{Ti}>\mathrm{Pb}>\mathrm{Cu}>\mathrm{Mo}>\mathrm{Cd}>\mathrm{As}>\mathrm{Ba}>\mathrm{V} \\
& >\mathrm{Sr}>\mathrm{Se}>\mathrm{Ce}>\mathrm{Pt} .
\end{aligned}
$$

The mean hourly concentration of non-sea salt sulfate (XACT) and non-refractory sulfate (ACSM) during the fireworks campaign at Marylebone Road was 2600 and $2000 \mathrm{ng} \mathrm{m}^{-3}$, respectively, with hourly concentration ranging from 240 to $10500 \mathrm{ng} \mathrm{m}^{-3} \mathrm{SO}_{4}$ (non-sea salt) and 58 to $8300 \mathrm{ng} \mathrm{m}^{-3}$ for non-refractory $\mathrm{SO}_{4}$.

The comparison of the XACT with the URG was carried out in $\mathrm{PM}_{10}$ at Marylebone Road during winter 2014/2015. The hourly concentration of water soluble anions and cations ranged from $154 \mathrm{ng} \mathrm{m}^{-3}(\mathrm{~K})$ to $1790 \mathrm{ng} \mathrm{m}^{-3}(\mathrm{Cl})$ compared to $145 \mathrm{ng} \mathrm{m}^{-3}(\mathrm{~K})$ to $2700 \mathrm{ng} \mathrm{m}^{-3}(\mathrm{Cl})$ in total element concentrations.

\subsubsection{Comparison with ICP-MS}

The filter comparison results were split by the two digestion methods: $\mathrm{HF} / \mathrm{HClO}_{4}$ and $\mathrm{HNO}_{3} / \mathrm{H}_{2} \mathrm{O}_{2}$. This had the additional advantage of grouping the two industrial campaigns that were carried out in $\mathrm{PM}_{10}$ and separating the campaign at Marylebone Road in $\mathrm{PM}_{2.5}$. LODs were not consistently higher for either the ICP-MS or the XACT measurements (Tables 3-5). All elements were compared using Deming regression and a summary of all calculated slopes and intercepts are given in Table 7 (including $R^{2}$ values); the corresponding figures are available in the supplementary information section. The XACT agreed well with the ICP-MS measurements and $R^{2}$ ranged from 0.50 to 1.00 and 0.67 to 0.99 , with a median of 0.91 and 0.95 , following $\mathrm{HF} / \mathrm{HClO}_{4}$ and $\mathrm{HNO}_{3} / \mathrm{H}_{2} \mathrm{O}_{2}$ digestion, respectively. Deming regression for Fe resulted in slopes that were not significantly different from unity for either subset. Slopes were also not significantly different from unity for $\mathrm{Ba}, \mathrm{Ca}, \mathrm{K}, \mathrm{Mn}$ and Ti following digestion with $\mathrm{HF} / \mathrm{HClO}_{4}$ and for $\mathrm{Cr}, \mathrm{Ni}, \mathrm{Pb}, \mathrm{V}$ and $\mathrm{Zn}$ following digestion with $\mathrm{HNO}_{3} / \mathrm{H}_{2} \mathrm{O}_{2}$. For the element As the XACT recorded significantly higher concentrations than those measured by ICP-MS, irrespective of digestion method. This was also the case for elements $\mathrm{Cu}, \mathrm{Pb}, \mathrm{Sr}$ and $\mathrm{Zn}$ after $\mathrm{HF} / \mathrm{HClO}_{4}$ digestion and for $\mathrm{Mn}$ after $\mathrm{HNO}_{3} / \mathrm{H}_{2} \mathrm{O}_{2}$ digestion. For the elements $\mathrm{Ni}$ (after $\mathrm{HF} / \mathrm{HClO}_{4}$ digestion), $\mathrm{Cu}$ and $\mathrm{Se}$ (after $\mathrm{HNO}_{3} / \mathrm{H}_{2} \mathrm{O}_{2}$ digestion) the concentrations measured by the XACT were significantly lower than those measured by the ICP-MS. Cr and V were not reported for $\mathrm{HF} / \mathrm{HClO}_{4}$ due to contamination of the $\mathrm{HClO}_{4}$ used in the digestion. In case of $\mathrm{Cd}$ and $\mathrm{Ce}$ a large number of hourly XACT concentrations were below the LOD, and thus the elements were excluded from further comparison.

There are a variety of possible reasons for the differences observed between the methods. In the case of the filter analysis, the blank filters were found to be variable and thus subtracted values may result in an under- or overestimation of the true concentration; the digestion recovery rates were not taken into account; many concentrations were close to the detection limit for the elements As in all campaigns and $\mathrm{Ni}$ during the Marylebone Road campaign. These stated reasons might influence the two digestions methods to different extents. Unfortunately, there was no opportunity to undertake both digestions on the same samples. To provide some insight into how the two digestion methods compared, the XACT measurements were grouped into concentration appropriate bins and the associated ICP-MS measurements from each digestion method were averaged and compared. These are shown in Supplement S6 (Deming regression of ICP-MS using different digestion methods). For the XACT, the standards used in calibrations were much higher than ambient concentrations and the calibration matrix differed from sample matrix (Indresand et al., 2013). Despite every effort being made to co-locate the sample inlets in all field trials, slight differences in inlet location, especially when close to 
(a)

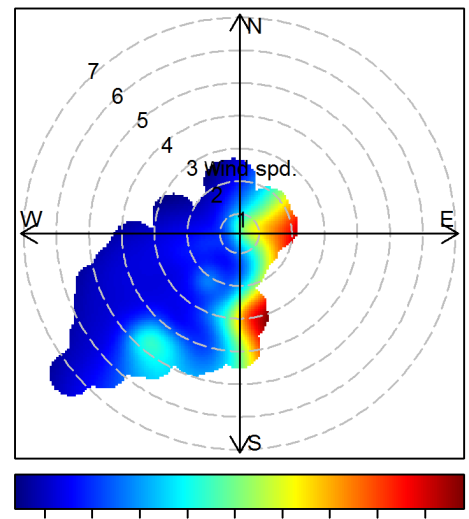

$\begin{array}{lllllllll}1.2 & 1.4 & 1.6 & 1.8 & 2 & 2.2 & 2.4 & 2.6 & 2.8\end{array}$

Mean $\mathrm{Cr}$ by ICP/MS $\left(\mathrm{ng} \mathrm{m}^{-3}\right)$ (b)

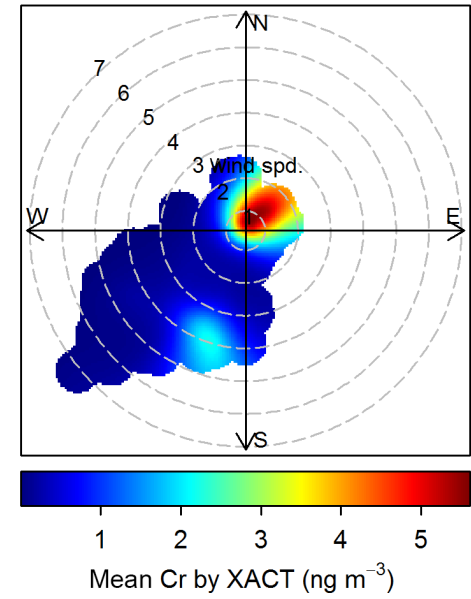

Figure 4. Polar plot of the $\mathrm{Cr}$ concentrations $\left(\mathrm{ng} \mathrm{m}^{-3}\right)$ in Pontardawe, Wales using daily ICP-MS measurements (a) and hourly XACT measurements (b).

Table 7. Deming regression results and coefficient of determination for XACT comparison with ICP-MS, separated by $\mathrm{HF} / \mathrm{HClO} 4$ and $\mathrm{HNO}_{3} / \mathrm{H}_{2} \mathrm{O}_{2}$ digestions.

\begin{tabular}{|c|c|c|c|c|c|c|}
\hline \multirow[b]{2}{*}{ Element } & \multicolumn{3}{|c|}{$\mathrm{HF} / \mathrm{HClO}_{4}$} & \multicolumn{3}{|c|}{$\mathrm{HNO}_{3} / \mathrm{H}_{2} \mathrm{O}_{2}$} \\
\hline & Slope & Intercept & $R^{2}$ & Slope & Intercept & $R^{2}$ \\
\hline As & $2.0(1.49-2.6)$ & $-0.33(-0.65-0)$ & 0.95 & $3.8(1.90-5.7)$ & $-0.23(-0.49-0.020)$ & 0.90 \\
\hline $\mathrm{Ba}$ & $1.04(0.73-1.35)$ & $-1.50(-4.8-1.79)$ & 0.98 & & & \\
\hline $\mathrm{Ca}$ & $1.14(0.84-1.45)$ & $-9.2(-31-13)$ & 0.70 & & & \\
\hline $\mathrm{Cr}$ & & & & $0.99(0.92-1.06)$ & $-1.70(-2.6-0.79)$ & 0.95 \\
\hline $\mathrm{Cu}$ & $1.31(1.05-1.57)$ & $0.29(-3.1-3.7)$ & 0.93 & $0.95(0.92-0.98)$ & $-0.03(-0.22-0.17)$ & 0.89 \\
\hline $\mathrm{Fe}$ & $1.26(0.65-1.87)$ & $-1.29(-220-210)$ & 0.89 & $1.03(0.99-1.07)$ & $-10(-18.19-2.0)$ & 0.96 \\
\hline $\mathrm{K}$ & $1.03(0.92-1.15)$ & $-1.23(-14.83-12.37)$ & 0.96 & & & \\
\hline $\mathrm{Mn}$ & $1.28(0.70-1.86)$ & $0.050(-1.97-2.1)$ & 0.92 & $1.10(1.07-1.14)$ & $0.17(0.020-0.32)$ & 0.99 \\
\hline $\mathrm{Ni}$ & $0.73(0.48-0.98)$ & $-0.20(-0.45-0.05)$ & 0.67 & $1.07(1.00-1.14)$ & $-1.21(-1.64-0.77)$ & 0.99 \\
\hline $\mathrm{Pb}$ & $1.44(1.31-1.57)$ & $0.140(-0.37-0.65)$ & 1.00 & $1.02(0.99-1.06)$ & $0.36(0.10-0.61)$ & 0.99 \\
\hline $\mathrm{Se}$ & & & & $0.83(0.73-0.94)$ & $-0.45(-0.57-0.33)$ & 0.67 \\
\hline $\mathrm{Sr}$ & $1.25(1.14-1.36)$ & $-0.0100(-0.19-0.17)$ & 1.00 & & & \\
\hline $\mathrm{Ti}$ & $1.44(0.68-2.2)$ & $0.91(-0.42-2.2)$ & 0.72 & & & \\
\hline V & & & & $0.87(0.74-1.01)$ & $-0.130(-0.22-0.04)$ & 0.89 \\
\hline $\mathrm{Zn}$ & $1.62(1.17-2.1)$ & $-4.4(-13.15-4.5)$ & 0.50 & $1.04(0.98-1.09)$ & $0.37(-0.58-1.31)$ & 0.94 \\
\hline
\end{tabular}

the road, could not be avoided. This and different temperatures of the sample inlets may also contribute to differences observed in concentrations. Nevertheless, the results of the XACT comparison with ICP-MS in this study are comparable to those reported in other studies (Furger et al., 2017).

\subsubsection{Comparison with ACSM at Marylebone Rd}

The hourly values of $\mathrm{S}$ and $\mathrm{Cl}$ measured with the XACT were used to calculate hourly non-sea salt sulfate $\left(\mathrm{SO}_{4}\right)$ based on their relative abundance in sea water (Millero et al. 2008). It should be noted that $\mathrm{Cl}$ is used in the absence of the preferred $\mathrm{Na}$ and $\mathrm{Cl}$ concentration measured could be partially depleted by reaction between $\mathrm{NaCl}$ and nitric acid $\left(\mathrm{HNO}_{3}\right)$. The hourly non-sea salt sulfate was com- pared to the hourly sulfate (predominantly ammonium sulfate) which is non-refractory measured by the ACSM (Chang et al., 2011). The mean (median) concentrations were 2600 (1880) $\mathrm{ng} \mathrm{m}^{-3}$ and 2000 (1460) $\mathrm{ng} \mathrm{m}^{-3}$, respectively. The time series of these measurements is shown in Fig. 5 and demonstrates the excellent temporal agreement, which is reflected by an $R^{2}$ of 0.93 . The correlation resulted in a slope of 1.41 (95\% confidence interval (CI) 1.35-1.46) and an intercept of 53 (95\% CI 13.4-93) $\mathrm{ng} \mathrm{m}^{-3}$. The larger non-sea salt $\mathrm{SO}_{4}$ means/medians and slope $>1$ likely resulted from measuring different size fractions; $\mathrm{PM}_{2.5}$ for the XACT vs. $\mathrm{PM}_{1}$ for the ACSM. 


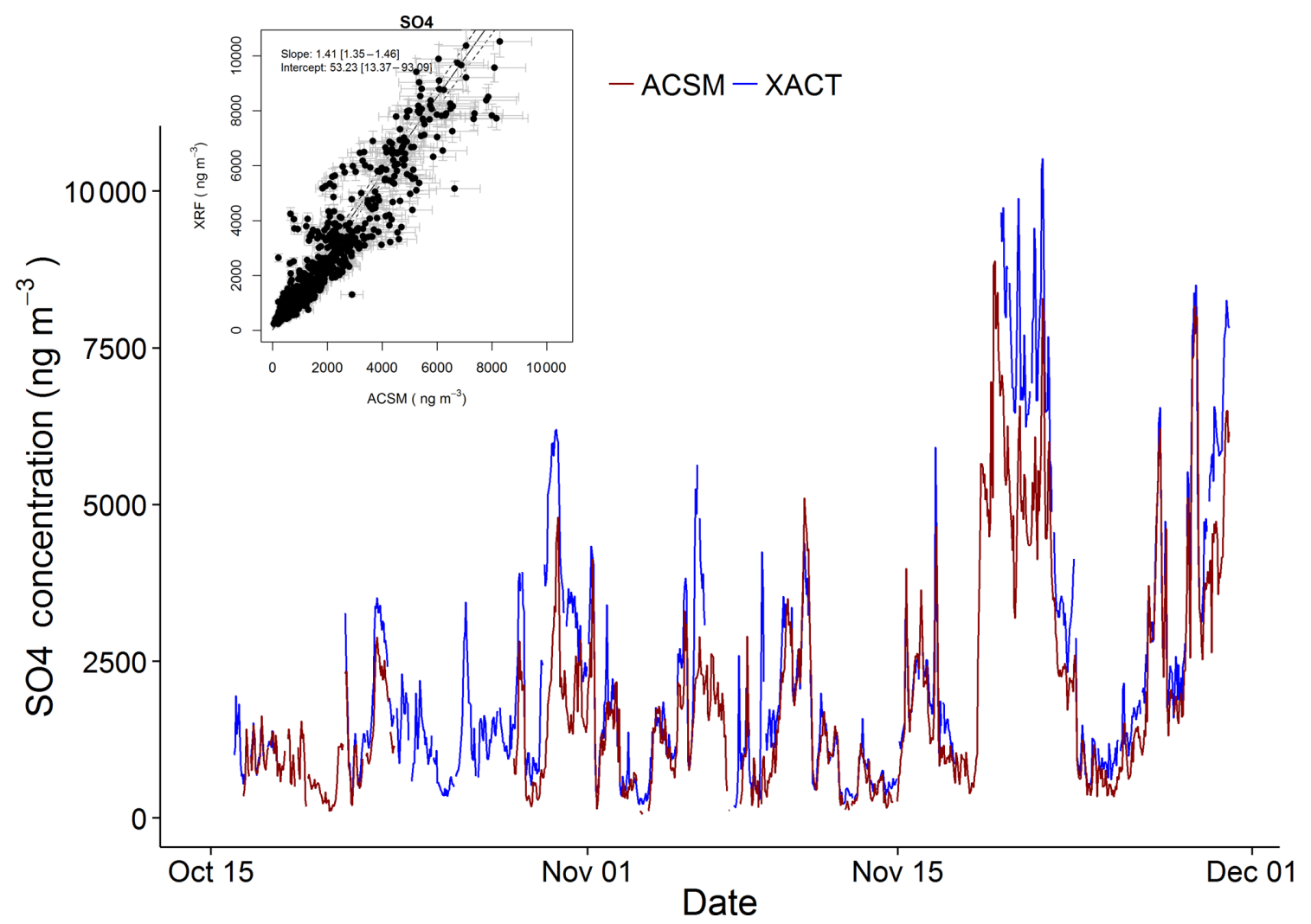

Figure 5. Time series of non-sea salt $\mathrm{SO}_{4}$ concentration (XACT, calculated) and non-refractory $\mathrm{SO}_{4}\left(\mathrm{ACSM}, \mathrm{measured}\right.$ in $\mathrm{ng}^{-3}$ at Marylebone Road, London.

\subsubsection{Comparison with URG}

Hourly concentrations of water-soluble $\mathrm{Cl}, \mathrm{K}$ and $\mathrm{Ca}$ measured by URG were compared to the hourly measured total $\mathrm{Cl}, \mathrm{K}$ and $\mathrm{Ca}$ measured by the XACT. Furthermore, hourly measured water-soluble $\mathrm{SO}_{4}$ (URG) was compared to hourly $\mathrm{SO}_{4}$ calculated from the $\mathrm{S}$ measurement by the XACT instrument (Table 6, Fig. 6). The XACT measured higher concentrations for all these components. The slopes were similar for the $\mathrm{SO}_{4}$ (1.65) and $\mathrm{Cl}(1.68)$ and slightly higher for $\mathrm{Ca}(1.89)$. Deming regression for $\mathrm{K}$ resulted in a very high slope (4.55) but this was likely the result of concentrations being close to the LOD for the URG, the result was consistent with the findings presented by Beccaceci et al. (2015). The $R^{2}$ for Ca, $\mathrm{Cl}, \mathrm{K}$ and $\mathrm{SO}_{4}$ was $0.86,0.93,0.36$ and 0.95 , respectively.

The higher concentrations measured by the XACT relative to the URG was likely caused by the low water-solubility of $\mathrm{Cl}, \mathrm{K}, \mathrm{Ca}$ and $\mathrm{S}$ containing minerals as well as the penetration efficiency of larger aerosols through the URG annular denuder (Beccaceci et al. 2015). The range of sources of these ions/elements resulted in variations in particle size and solubility and hence the relative response of the two instruments. When considering solubility, the larger slopes are associated with the least soluble compounds. In order of decreasing solubility (and increasing slope) $\mathrm{SO}_{4}$ exists pre- dominately as $\left(\mathrm{NH}_{4}\right)_{2} \mathrm{SO}_{4}$ (solubility of $754 \mathrm{~g} \mathrm{~L}^{-1}$ in water), $\mathrm{Cl}$ is principally from marine sources as $\mathrm{NaCl}$ (solubility of $359 \mathrm{~g} \mathrm{~L}^{-1}$ in water at $20^{\circ} \mathrm{C}$ ); $\mathrm{Ca}$ in the urban environment is typically from mineral or construction sources and is comprised of $\mathrm{CaCO}_{3}$ and $\mathrm{CaSO}_{4} \cdot 2 \mathrm{H}_{2} \mathrm{O}$ (solubilities of 0.013 and $2.55 \mathrm{~g} \mathrm{~L}^{-1}$ respectively) as well as calcium silicates (which are insoluble) (Dean and Lange, 1999). When considering particle size, the sources of aerosols containing $\mathrm{Cl}, \mathrm{K}, \mathrm{Ca}$ and $\mathrm{S}$ are often larger than $\mathrm{PM}_{2.5}$ and may therefore be influenced by the reduced penetration efficiency of the URG annular denuder (Dick et al., 1995; Visser et al., 2015b). The chemical composition of different size fractions was sampled using a rotating drum impactor (RDI) and analysed with synchrotron radiation-induced X-ray fluorescence spectrometry (SR-XRF) during a winter campaign at Marylebone Road in 2012 (Visser et al., 2015b) and the percentage of the element in the $\mathrm{PM}_{10-2.5}$ fraction can be used to highlight how these elements are distributed between the fine and coarse particle sizes: S 35\%, K 57\%, Ca $72 \%$ and $\mathrm{Cl} 73 \%$. This illustrates that a sampling bias, due to the penetration efficiency of the annular denuder may play a role in the difference between the URG and the XACT; however, due to the additional variation in solubility this is difficult to quantify. 

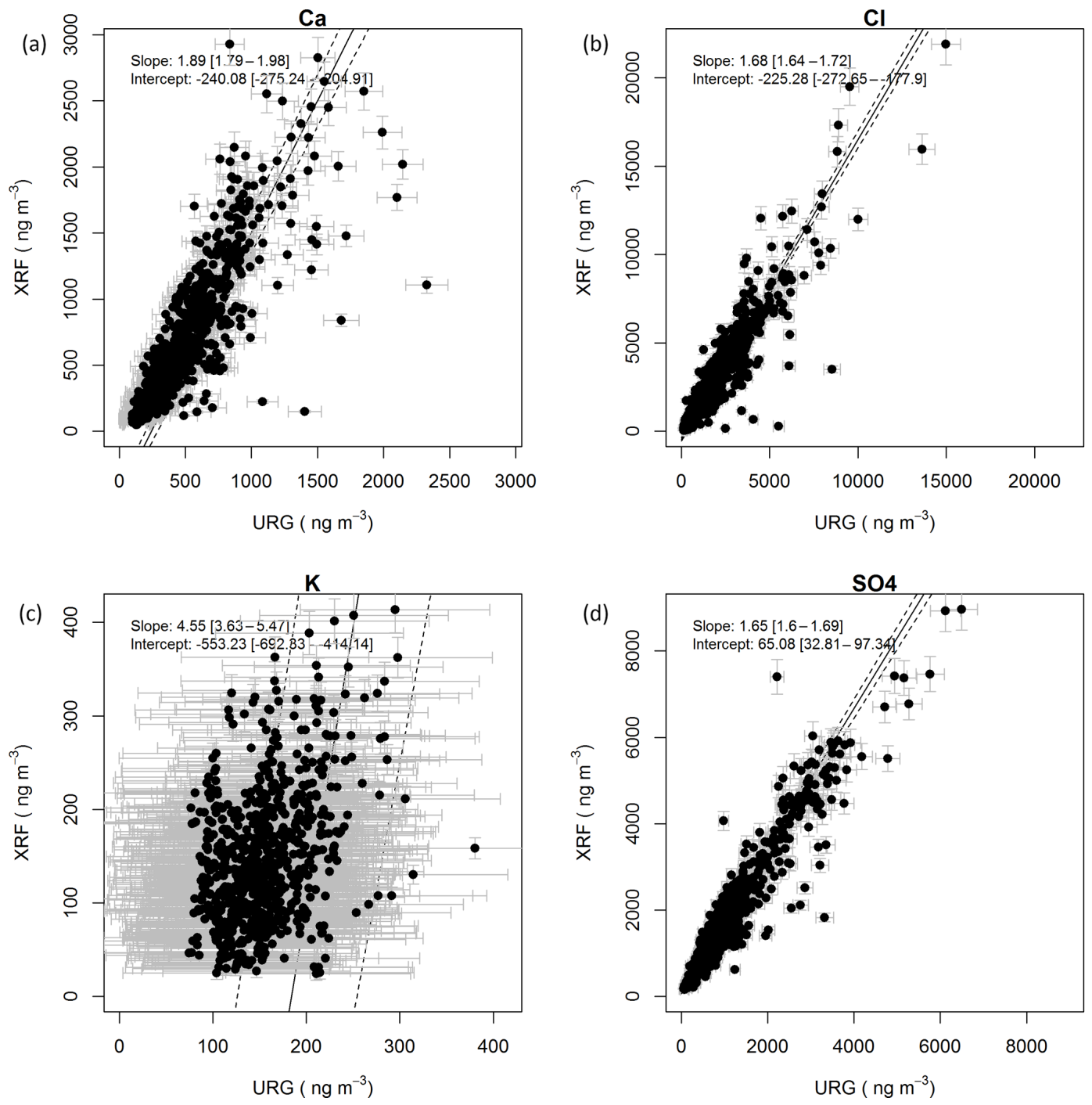

Figure 6. Deming regression of water soluble $\mathrm{Ca}(\mathbf{a}), \mathrm{Cl}(\mathbf{b}), \mathrm{K}(\mathbf{c})$ and $\mathrm{SO}_{4}(\mathbf{d})$ as measured by $\mathrm{URG}$ and $\mathrm{Ca}, \mathrm{Cl}, \mathrm{K}$ and calculated $\mathrm{SO}_{4}$ (from elemental S) measured by XACT $\left(\mathrm{ng} \mathrm{m}^{-3}\right.$ ) at Marylebone Road, London.

\subsection{Laboratory based filter analysis using the XACT}

With a mean $R^{2}$ of 0.95 daily concentrations measured on the filter by the XACT compared well with the measurements made by the XACT when deployed in the field in Tinsley, Sheffield. The resulting regression slopes are compared with those from the ICP-MS comparison (Fig. 7). The small sample number $(N=12)$ resulted in a higher uncertainty in the slopes but in general the slopes were comparable to those from the ICP-MS filter analyses. The intercepts for most elements were not significantly different from 0 . The slopes for the elements $\mathrm{Ba}, \mathrm{Cl}, \mathrm{Cr}, \mathrm{Cu}, \mathrm{Mn}, \mathrm{Ni}, \mathrm{Sr}, \mathrm{V}$ and $\mathrm{Zn}$ were not significantly different from the $1: 1$ line. For the elements $\mathrm{As}, \mathrm{Ca}, \mathrm{Fe}$ and $\mathrm{Ti}$ the XACT measurements were lower when deployed in the field than when measuring the $24 \mathrm{~h}$ filter samples. Whereas for the elements $\mathrm{K}, \mathrm{Mo}, \mathrm{Pb}, \mathrm{S}$ and $\mathrm{Se}$ online field measurements resulted in higher results than off-line filter measurements. Reasons for the discrepancies in the slopes may be caused by the difference between the filter material and analysis time used for the filter samples (Zefluor, $15 \mathrm{~min}$ ) in comparison to the online method (proprietary PTFE tape, $1 \mathrm{~h}$ ). Additionally the fitting routine used in the deconvolution software is optimised for the filter tape used and might also contribute to the observed differences. Full results can be found in the supplementary information.

Punching and subsequent filter analysis was found to be practically achievable, although time consuming, when compared to automated laboratory techniques. 


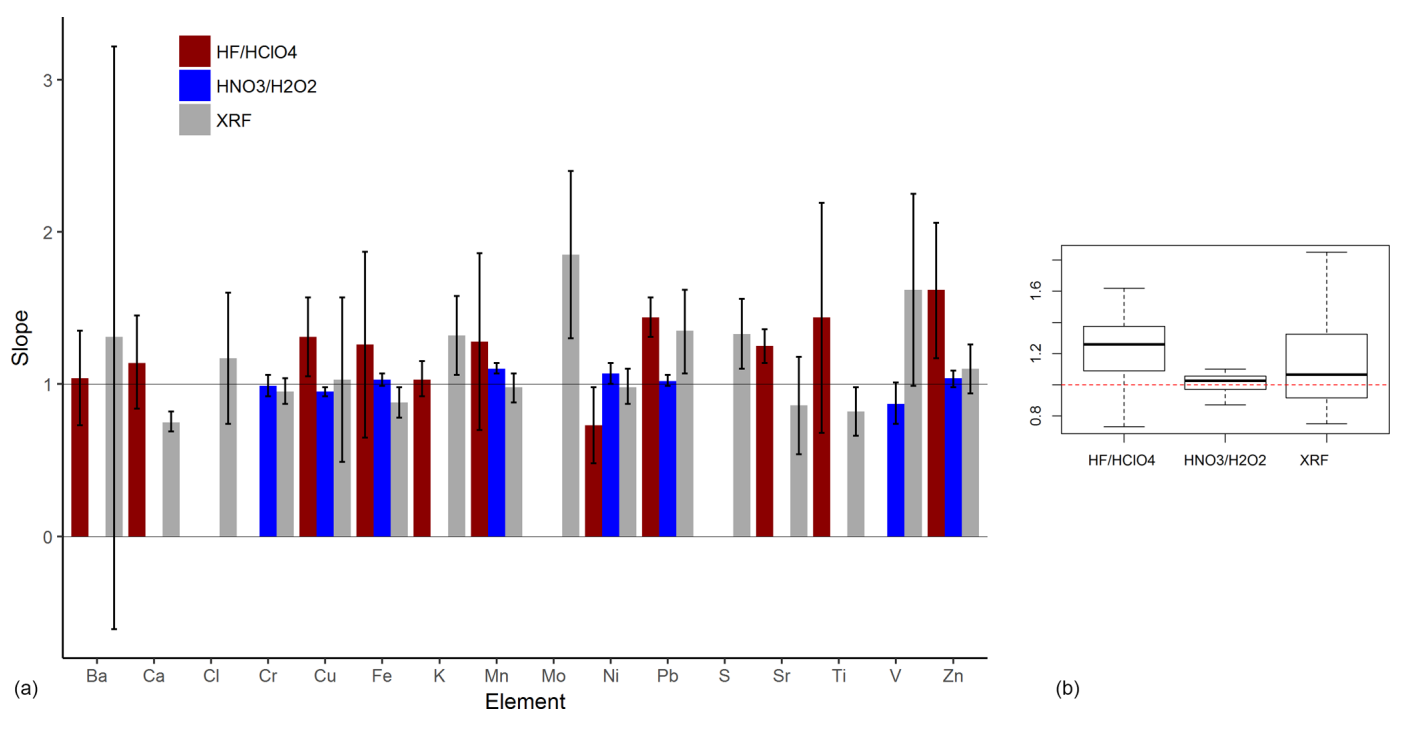

Figure 7. Slope values (+95\% confidence interval) of Deming regressions (XACT vs. ICP-MS (split in $\mathrm{HF}_{2} \mathrm{HClO}_{4}$ and $\mathrm{HNO}_{3} / \mathrm{H}_{2} \mathrm{O}_{2}$ digestion) and XACT vs. XACT, filter), split by element (a) and corresponding box-and-whisker plots split by method (b).

\section{Conclusions}

This study was performed to evaluate the XACT 625 in the field and under laboratory conditions. In the field, the XACT was evaluated in three contrasting environments and compared to laboratory-based ICP-MS analysis as well as alternative high time resolution instrumentation. The XACT was found to be a highly reliable measurement instrument which showed an excellent correlation with standardised laboratory analysis (ICP-MS) albeit with a slight overall positive bias (median 1.07). Differences in the individual results were element specific but generally attributable to a combination of variable filter blank levels, recovery rates from acid digestion, instrument calibration, sampling temperature and small differences in inlet location. When compared to the alternative aerosol mass spectrometry and ion chromatography based high time resolution techniques, the XACT showed good temporal agreement but with a clear positive difference (median 1.68) compared to the ICP-MS; this was likely due to the differences in the size selection methodology employed by the different techniques as well as particle volatility and water solubility. However, these differences (size, solubility and volatility) could be utilised to provide information about different sources and their contributions; such as the difference between refractory sodium chloride and nonrefractory ammonium chloride.

The laboratory experiment, which compared the XACT measurements of the elemental constituents of generated aerosols with the mass measured using a TEOM, proved to be a successful method for verifying the response of the XACT over environmentally relevant elemental concentrations. The slopes were close to, and not significantly different from, unity $(0.94-0.99)$. This suggests that the XACT accurately measures elemental ambient aerosol composition and that the positive bias, when compared to the ICP-MS measurements identified in the field experiments in all locations, was not due to the XACT calibration but more likely due to the remaining reasons listed above. It further shows that generated aerosols can be used to calibrate the XACT to provide ongoing quality assurance checks.

An ambient filter sampling analysis technique, using the $\mathrm{XACT}$ as a laboratory based instrument, was also evaluated. The concentrations measured on the sampled filter compared well with the in situ XACT with median slopes of 1.07 and was therefore comparable with the ICP-MS filter-based technique. This technique diversifies further the use of the $\mathrm{XACT}$, especially if the instrument has downtime between campaigns. This technique also allows a direct comparison of the XACT and other XRF systems using a filter sample.

Future work should include a repetition of the laboratory calibration using an overall lower range of standards and combining solutions in order to have a more complex particle composition. A standard reference material, either in solution or on filter should also be included in future calibration tests. Further, to develop the filter analysis method using the XACT and piloted in this study, different filter materials should be tested and the deconvolution approach optimised if necessary.

Data availability. ICP-MS measurements on filters made at Pontardawe and Sheffield are available from https://uk-air.defra.gov.uk/ data/metals-data. Additional datasets are available upon request to the corresponding author. 


\section{The Supplement related to this article is available online at https://doi.org/10.5194/amt-11-3541-2018-supplement.}

Author contributions. AHT: experiment design (XACT filter analysis), field and laboratory experiments, data ratification and analysis, manuscript preparation with contributions from all co-authors, AF: field experiments and data analysis; MP: field experiments and ACSM data ratification; SHH: field experiments (Marylebone Road), TCC: laboratory experiments (calibration test of $\mathrm{Cl}, \mathrm{K}$ and S), AP: laboratory experiments (filter analysis), RJCBL uncertainty calculations, SLG: filter analysis (Wales/Sheffield), NG: filter digestion (Marylebone Road), KP: technical input for XACT, FJK: manuscript review, DCG: experiment design (laboratory calibration test), field and laboratory experiments, uncertainty calculations, manuscript overview.

Competing interests. Krag Petterson is employed by Cooper Environmental Services, the manufacturer of the instrument and had input into the manuscript preparation from a technical perspective.

Disclaimer. This manuscript has not been published and is not under consideration for publication elsewhere.

Acknowledgements. This study has been partly funded by the Welsh Government under contract C224/2015/2016 and by the UK Department for Environment Food \& Rural Affairs under contract AQ0740. It used equipment funded by the Natural Environment Research Council Traffic Grant (NE/1007806/1) and by the UK Department for the Environment and Rural Affairs Black Smoke and Heavy Metals Monitoring Networks.

Edited by: Willy Maenhaut

Reviewed by: five anonymous referees

\section{References}

AQEG: Particulate Matter in the United Kingdom, Air Quality Expert Group, Department for Environment, Food and Rural Affairs, London, 6-28, 2005.

Beccaceci, S., McGhee, E. A., Brown, R. J. C., and Green, D. C.: A comparison between a semi-continuous analyzer and filter-based method for measuring anion and cation concentrations in $\mathrm{PM}_{10}$ at an urban background site in London, Aerosol Sci. Tech., 49, 793-801, 2015

Brown, R. J. C., Yardley, R. E., Muhunthan, D., Butterfield, D. M., Williams, M., Woods, P. T., Brown, A. S., and Goddard, S. L.: Twenty-five years of nationwide ambient metals measurement in the United Kingdom: concentration levels and trends, Environ. Monit. Assess., 142, 127-140, 2008.

Brunekreef, B. and Holgate, S. T.: Air pollution and health, Lancet, 360, 1233-1242, 2002.
Bukowiecki, N., Hill, M., Gehrig, R., Zwicky, C. N., Lienemann, P., Hegedus, F., Falkenberg, G., Weingartner, E., and Baltensperger, U.: Trace metals in ambient air: Hourly size-segregated mass concentrations determined by Synchrotron-XRF, Environ. Sci. Technol., 39, 5754-5762, 2005.

CEN: Ambient air - Standard gravimetric measurement method for the determination of the $\mathrm{PM}_{10}$ or $\mathrm{PM}_{2.5}$ mass concentration of suspended particulate matter (EN 12341:2014), European Committee for Standardization (CEN), Brussels. 2014.

Chang, R. Y.-W., Leck, C., Graus, M., Müller, M., Paatero, J., Burkhart, J. F., Stohl, A., Orr, L. H., Hayden, K., Li, S.-M., Hansel, A., Tjernström, M., Leaitch, W. R., and Abbatt, J. P. D.: Aerosol composition and sources in the central Arctic Ocean during ASCOS, Atmos. Chem. Phys., 11, 10619-10636, https://doi.org/10.5194/acp-11-10619-2011, 2011.

Chen, L. C. and Lippmann, M.: Effects of metals within ambient air particulate matter (PM) on human health, Inhal. Toxicol., 21, 1-31, 2009.

Chow, J. C., Lowenthal, D. H., Chen, L. W. A., Wang, X. L., and Watson, J. G.: Mass reconstruction methods for $\mathrm{PM}_{2.5}$ : a review, Air Qual. Atmos. Hlth., 8, 243-263, 2015.

Chu, S. H.: $\mathrm{PM}_{2.5}$ episodes as observed in the speciation trends network, Atmos. Environ., 38, 5237-5246, 2004.

Crenn, V., Sciare, J., Croteau, P. L., Verlhac, S., Fröhlich, R., Belis, C. A., Aas, W., Äijälä, M., Alastuey, A., Artiñano, B., Baisnée, D., Bonnaire, N., Bressi, M., Canagaratna, M., Canonaco, F., Carbone, C., Cavalli, F., Coz, E., Cubison, M. J., Esser-Gietl, J. K., Green, D. C., Gros, V., Heikkinen, L., Herrmann, H., Lunder, C., Minguillón, M. C., Močnik, G., O’Dowd, C. D., Ovadnevaite, J., Petit, J. E., Petralia, E., Poulain, L., Priestman, M., Riffault, V., Ripoll, A., Sarda-Estève, R., Slowik, J. G., Setyan, A., Wiedensohler, A., Baltensperger, U., Prévôt, A. S. H., Jayne, J. T., and Favez, O.: ACTRIS ACSM intercomparison - Part 1: Reproducibility of concentration and fragment results from 13 individual Quadrupole Aerosol Chemical Speciation Monitors (Q-ACSM) and consistency with co-located instruments, Atmos. Meas. Tech., 8, 5063-5087, https://doi.org/10.5194/amt-8-50632015, 2015.

Dean, J. A. and Lange, N. A.: Lange's Handbook of Chemistry, McGraw-Hill, 15th Ed., 3.1-5.172, 1999.

Deming, W. E.: Statistical adjustment of data, John Wiley \& Sons; Chapman \& Hall, New York: London, 261 pp., 1943.

Dick, W., Huang, P. F., and McMurry, P. H.: Characterization of 0.02 to $1.0 \mu \mathrm{m}$ particle losses in Perma Pure dryers: dependency on size, charge and relative humidity, PTL Publication No. 936: Particle Technology Laboratory, Department of Mechanical Engineering, University of Minnesota, Minneapolis, MN 55455, 1 15, 1995.

Font, A., Prietsman, M., Tremper, A., Carslaw, D., and Green, D. C.: Identifying key sources of emissions of problem pollutants in Wales: a research collaboration to utilise novel monitoring and data analysis assessment techniques to drive innovation - Pontardawe Report, Environmental Research Group, King's College London, London, 2017.

Formenti, P., Prati, P., Zucchiatti, A., Lucarelli, F., and Mando, P. A.: Aerosol study in the town of Genova with a PIXE analysis, Nucl. Instrum. Meth. B, 113, 359-362, 1996.

Furger, M., Minguillón, M. C., Yadav, V., Slowik, J. G., Hüglin, C., Fröhlich, R., Petterson, K., Baltensperger, U., and Prévôt, A. S. 
H.: Elemental composition of ambient aerosols measured with high temporal resolution using an online XRF spectrometer, Atmos. Meas. Tech., 10, 2061-2076, https://doi.org/10.5194/amt10-2061-2017, 2017.

Fuzzi, S., Baltensperger, U., Carslaw, K., Decesari, S., van Der Gon, H. D., Facchini, M. C., Fowler, D., Koren, I., Langford, B., Lohmann, U., Nemitz, E., Pandis, S., Riipinen, I., Rudich, Y., Schaap, M., Slowik, J. G., Spracklen, D. V., Vignati, E., Wild, M., Williams, M., and Gilardoni, S.: Particulate matter, air quality and climate: lessons learned and future needs, Atmos. Chem. Phys., 15, 8217-8299, https://doi.org/10.5194/acp15-8217-2015, 2015.

Goddard, S. L., Brown, R. J. C., Butterfield, D. M., McGhee, E. A., Robins, C., Beccaceci, S., Lilley, A., Bradshaw, C., and Haynes, E.: Annual Report for 2015 on the UK Heavy Metals Monitoring Network, National Physical Laboratory, 13-36, 2016.

Godri, K. J., Green, D. C., Fuller, G. W., Dall'Osto, M., Beddows, D. C., Kelly, F. J., Harrison, R. M., and Mudway, I. S.: Particulate oxidative burden associated with firework activity, Environ. Sci. Technol., 44, 8295-8301, 2010.

Hamad, S., Green, D., and Heo, J.: Evaluation of health risk associated with fireworks activity at central London, Air Qual. Atmos. Hlth., 9, 735-741, 2016.

Indresand, H., White, W. H., Trzepla, K., and Dillner, A. M.: Preparation of sulfur reference materials that reproduce atmospheric particulate matter sample characteristics for XRF calibration, XRay Spectrom., 42, 359-367, 2013.

Jeong, J. H., Shon, Z. H., Kang, M., Song, S. K., Kim, Y. K., Park, J., and Kim, H.: Comparison of source apportionment of $\mathrm{PM}_{2.5}$ using receptor models in the main hub port city of East Asia: Busan, Atmos. Environ., 148, 115-127, 2017.

Kelly, F. J. and Fussell, J. C.: Air pollution and public health: emerging hazards and improved understanding of risk, Environ. Geochem. Hlth., 37, 631-649, 2015.

Kelly, F. J., Fuller, G. W., Walton, H. A., and Fussell, J. C.: Monitoring air pollution: Use of early warning systems for public health, Respirology, 17, 7-19, 2012.

Liu, P. S. K., Deng, R., Smith, K. A., Williams, L. R., Jayne, J. T., Canagaratna, M. R., Moore, K., Onasch, T. B., Worsnop, D. R., and Deshler, T.: Transmission efficiency of an aerodynamic focusing lens system: Comparison of model calculations and laboratory measurements for the Aerodyne Aerosol Mass Spectrometer, Aerosol Sci. Tech., 41, 721-733, 2007.

Middlebrook, A. M., Bahreini, R., Jimenez, J. L., and Canagaratna, M. R.: Evaluation of composition-dependent collection efficiencies for the aerodyne aerosol mass spectrometer using field data, Aerosol Sci. Tech., 46, 258-271, 2012.

Millero, F. J., Feistel, R., Wright, D. G., and McDougall, T. J.: The composition of standard seawater and the definition of the reference-composition salinity scale, Deep Sea Res. Part I: Oceanogr. Res. Pap., 55, 50-72, 2008.

Moreno, T., Querol, X., Alastuey, A., Minguillon, M. C., Pey, J., Rodriguez, S., Miro, J. V., Felis, C., and Gibbons, W.: Recreational atmospheric pollution episodes: Inhalable metalliferous particles from firework displays, Atmos. Environ., 41, 913-922, 2007.

Ng, N. L., Herndon, S. C., Trimborn, A., Canagaratna, M. R., Croteau, P. L., Onasch, T. B., Sueper, D., Worsnop, D. R., Zhang, Q., Sun, Y. L., and Jayne, J. T.: An aerosol chemical speciation monitor (ACSM) for routine monitoring of the composition and mass concentrations of ambient aerosol, Aerosol Sci. Tech., 45, 780-794, 2011.

Orsini, D. A., Ma, Y., Sullivan, A., Sierau, B., Baumann, K., and Weber, R. J.: Refinements to the particle-into-liquid sampler (PILS) for ground and airborne measurements of water soluble aerosol composition, Atmos. Environ., 37, 1243-1259, 2003.

Pandey, S. K., Kim, K. H., and Brown, R. J. C.: A review of techniques for the determination of polycyclic aromatic hydrocarbons in air, TrAC-Trend Anal. Chem., 30, 1716-1739, 2011.

Park, S. S., Cho, S. Y., Jo, M. R., Gong, B. J., Park, J. S., and Lee, S. J.: Field evaluation of a near-real time elemental monitor and identification of element sources observed at an air monitoring supersite in Korea, Atmos. Pollut. Res., 5, 119-128, 2014.

Rumsey, I. C., Cowen, K. A., Walker, J. T., Kelly, T. J., Hanft, E. A., Mishoe, K., Rogers, C., Proost, R., Beachley, G. M., Lear, G., Frelink, T., and Otjes, R. P.: An assessment of the performance of the Monitor for AeRosols and GAses in ambient air (MARGA): a semi-continuous method for soluble compounds, Atmos. Chem. Phys., 14, 5639-5658, https://doi.org/10.5194/acp-145639-2014, 2014.

US-EPA: Determination of metals in ambient particulate matter using X-Ray Fluorescence (XRF) Spectroscopy, Agency, edited by: US-EPA (US Environmental Protection Agency), Cincinnati, OH 45268, USA, 1999.

US-EPA: Environmental Technology Verification Report. Cooper Environmental Services LLC Xact 625 Particulate Metals Monitor, Report no. EPA/600/R-12/680, Agency, edited by: US-EPA (US Environmental Protection Agency), Cincinnati, OH 45268, USA, 2012.

Vecchi, R., Bernardoni, V., Cricchio, D., D’Alessandro, A., Fermo, P., Lucarelli, F., Nava, S., Plazzalunga, A., and Valli, G.: The impact of fireworks on airborne particles, Atmos. Environ., 42, 1121-1132, 2008.

Visser, S., Slowik, J. G., Furger, M., Zotter, P., Bukowiecki, N., Canonaco, F., Flechsig, U., Appel, K., Green, D. C., Tremper, A. H., Young, D. E., Williams, P. I., Allan, J. D., Coe, H., Williams, L. R., Mohr, C., Xu, L., Ng, N. L., Nemitz, E., Barlow, J. F., Halios, C. H., Fleming, Z. L., Baltensperger, U., and Prévôt, A. S. H.: Advanced source apportionment of size-resolved trace elements at multiple sites in London during winter, Atmos. Chem. Phys., 15, 11291-11309, https://doi.org/10.5194/acp-15-112912015, 2015a.

Visser, S., Slowik, J. G., Furger, M., Zotter, P., Bukowiecki, N., Dressler, R., Flechsig, U., Appel, K., Green, D. C., Tremper, A. H., Young, D. E., Williams, P. I., Allan, J. D., Herndon, S. C., Williams, L. R., Mohr, C., Xu, L., Ng, N. L., Detournay, A., Barlow, J. F., Halios, C. H., Fleming, Z. L., Baltensperger, U., and Prevot, A. S. H.: Kerb and urban increment of highly time-resolved trace elements in $\mathrm{PM}_{10}, \mathrm{PM}_{2.5}$ and $\mathrm{PM}_{1.0}$ winter aerosol in London during ClearfLo 2012, Atmos. Chem. Phys., 15, 2367-2386, https://doi.org/10.5194/acp15-2367-2015, 2015b.

Weber, R. J., Orsini, D., Daun, Y., Lee, Y. N., Klotz, P. J., and Brechtel, F.: A particle-into-liquid collector for rapid measurement of aerosol bulk chemical composition, Aerosol Sci. Tech., 35, 718727, 2001.

WHO: Review of evidence on health aspects of air pollution - REVIHAAP Project, WHO, Copenhagen, technical report, 2013. 
Yardley, R. E., Sweeney, B. P., Butterfield, D., Quincey, P., and Fuller, G. W.: Estimation of Measurement Uncertainty in Network Data, National Pysical Laboratory, 13-36, 2007. 